\title{
Direct Observation of $\beta$-Aryl Eliminations from Rh(I) Alkoxides
}

\author{
Pinjing Zhao, Christopher D. Incarvito, and John F. Hartwig* \\ Department of Chemistry, Yale University, PO Box 208107, New Haven CT, 06520-8107
}

\section{Supporting Information}

\section{Table of Contents}

General Experimental Procedure and Reagent Availability. S2

General Procedure for the Preparation of Bis(triethylphosphine)-Ligated Rh(I) Alkoxides. S2

Preparation of Rh(I) Alkoxides 2a, 2c. $\quad$ S3

General Procedure for the Generation and in situ NMR Characterization of Unstable S4 Bis(triethylphosphine)-Ligated Rh(I) Alkoxides.

Generation and in situ NMR Characterization of Rh(I) Alkoxides 2a, 2c.

General Procedure for the Preparation of Tris(triethylphosphine)-Ligated Rh(I) Alkoxides. S5

Preparation of Rh(I) Alkoxides 3b-3e. $\quad$ S5

$\beta$-Phenyl Eliminations of $\mathrm{Rh}(\mathrm{I})$ Alkoxides. $\quad$ S8

Representative Procedure for the Kinetic Experiments Conducted on $\beta$-Phenyl S10 Elimination of $\left(\mathrm{PEt}_{3}\right)_{2} \mathrm{RhOCPh}_{3}$ (2a) with added $\mathrm{PEt}_{3}$.

Figure S1. Representative Kinetic Plot for $\beta$-Phenyl Elimination of $\left(\mathrm{PEt}_{3}\right)_{2} \mathrm{RhOCPh}_{3}(\mathbf{2 a}) \quad \mathrm{S} 11$ with Added $\mathrm{PEt}_{3}$.

References.

Figure S2-S4. NMR Spectra of $\left(\mathrm{PEt}_{3}\right)_{3} \mathrm{RhOC}_{(\mathrm{Me}) \mathrm{Ph}_{2}(\mathbf{3 b})} \quad \mathrm{S} 13$

Figure S5-S8. NMR Spectra of $\left(\mathrm{PEt}_{3}\right)_{3} \mathrm{RhOC}\left(\mathrm{CF}_{3}\right) \mathrm{Me}_{2}(\mathbf{3 e}) \quad \mathrm{S} 16$

Experimental Procedure for the X-ray Diffraction of $\left(\mathrm{PEt}_{3}\right)_{2} \mathrm{RhOCPh}_{3}(\mathbf{2 a}) . \quad \mathrm{S} 20$

Table S1. Crystal Data and Structure Refinement for 2a. $\quad$ S22

Table S2. Atomic Coordinates (x 104) and Equivalent Isotropic Displacement Parameters S23 $\left(\AA^{2} \times 10^{3}\right)$ for $\mathbf{2 a}$.

Table S3. Bond Lengths and Angles for 2a.

S25

Table S4. Anisotropic Displacement Parameters $\left(\AA^{2} \times 10^{3}\right)$ for 2a. $\quad$ S27

Table S5. Hydrogen Coordinates $\left(\mathrm{x}_{10^{4}}\right)$ and Isotropic Displacement Parameters $\left(\AA^{2} \mathrm{x} \quad \mathrm{S} 29\right.$ $10^{3}$ ) for $\mathbf{2 a}$.

Figure S9. ORTEP diagram of $\mathbf{2 a}$. 
General. Unless noted otherwise, all manipulations were carried out under an inert atmosphere using a nitrogen-filled glovebox or standard Schlenk techniques. All glassware was oven-dried for approximately $1 \mathrm{~h}$ prior to use. THF, $\mathrm{Et}_{2} \mathrm{O}$, toluene, benzene and pentane were collected from a solvent purification system containing a $1 \mathrm{~m}$ column of activated alumina. $\mathrm{C}_{6} \mathrm{D}_{6}$, $\mathrm{C}_{6} \mathrm{D}_{12}$ and THF- $d_{8}$ were dried over sodium benzophenone ketyl and vacuum transferred prior to use. ${ }^{1} \mathrm{H}$ NMR spectra were obtained on a $400-$ or $500-\mathrm{MHz}$ spectrometer, and chemical shifts were recorded relative to residual protiated solvent. ${ }^{13} \mathrm{C}$ NMR spectra were obtained at 100.6 or 125.8 $\mathrm{MHz}$ on a $400-$ or $500-\mathrm{MHz}$ instrument, and chemical shifts were recorded relative to the solvent resonance. Both ${ }^{1} \mathrm{H}$ NMR and ${ }^{13} \mathrm{C}$ NMR chemical shifts are reported in parts per million downfield from tetramethylsilane. ${ }^{31} \mathrm{P}$ NMR spectra were obtained at $161.9 \mathrm{MHz}$, and chemical shifts are reported in parts per million downfield of $85 \% \mathrm{H}_{3} \mathrm{PO}_{4}$.

$\mathrm{PEt}_{3}, \mathrm{LiN}\left(\mathrm{SiMe}_{3}\right)_{2}$, tetramethylsilane, phenylmagnesium bromide, trityl alcohol (1a), 2phenyl-2-propanol (1b), 9-phenyl-9-xanthenol (1c), 9-phenyl-9-fluorenol (1d), 2trifluoromethyl-2-propanol (1e), benzophenone (5a), acetophenone (5b), xanthone (5c) and fluorenone (5d) were commercially available and used as received. $\left[(\mathrm{COE})_{2} \mathrm{Rh}(\mu-\mathrm{Cl})\right]_{2}{ }^{1}{ }^{1}$ $\left(\mathrm{PEt}_{3}\right)_{2} \mathrm{RhN}\left(\mathrm{SiMe}_{3}\right)_{2},{ }^{2}$ and $\left(\mathrm{PEt}_{3}\right)_{3} \mathrm{RhPh}^{3}$ (4) were prepared according to literature procedures. Kinetic studies of samples heated in an oil bath were conducted with a thermostated bath in which the temperature fluctuation was $\pm 0.1^{\circ} \mathrm{C}$. The temperature of the samples of reactions monitored by NMR spectroscopy was measured with a thermocouple inserted through the instrument into a toluene solution in an NMR sample tube.

General Procedure for the Preparation of Bis(triethylphosphine) Rh(I) Alkoxides (2a, 2c). Into a $20 \mathrm{~mL}$ scintillation vial equipped with a magnetic stir bar was placed $\left(\mathrm{PEt}_{3}\right)_{2} \mathrm{RhN}\left(\mathrm{SiMe}_{3}\right)_{2}(200 \mathrm{mg}, 0.40 \mathrm{mmol})$ and $\mathrm{Et}_{2} \mathrm{O}(5 \mathrm{~mL})$. The corresponding tertiary alcohol 
(0.40 mmol, 1.0 equiv) was dissolved in $\mathrm{Et}_{2} \mathrm{O}(2 \mathrm{~mL})$ and added dropwise under stirring. An instant color change from dark purple to maroon or brown was observed. The solution was stirred at room temperature for 5-10 min until the rhodium silylamide was fully converted, as determined by ${ }^{31} \mathrm{P}$ NMR spectroscopy. The volatile materials were removed under reduced pressure, affording the crude rhodium alkoxide product as a precipitate. Further purification was achieved by crystallization from $\mathrm{Et}_{2} \mathrm{O}$ at $-35^{\circ} \mathrm{C}$.

Preparation of $\left(\mathbf{P E t}_{3}\right)_{2} \mathbf{R h O C P h}_{3}$ (2a). The general procedure for the preparation of bis(triethylphosphine)-ligated rhodium alkoxide complexes, followed by crystallization from $\mathrm{Et}_{2} \mathrm{O}$ at $-35^{\circ} \mathrm{C}$, gave maroon crystals of $\mathbf{2 a}(175 \mathrm{mg}, 73 \%$ yield $) .{ }^{1} \mathrm{H}$ NMR $\left(400 \mathrm{MHz}, \mathrm{THF}-d_{8}\right)$ : ठ 1.00-1.10 (m, 18H, $\mathrm{CH}_{3}$ signals for $\mathrm{PEt}_{3}$ ligands), 1.25-1.32 (m, 12H, $\mathrm{CH}_{2}$ signals for $\mathrm{PEt}_{3}$ ligands), 7.03 (t, $J=7.5 \mathrm{~Hz}, 3 \mathrm{H}$, para protons for the triphenylmethoxy ligand), 7.13 (t, $J=7.4 \mathrm{~Hz}$, $6 \mathrm{H}$, meta protons), 7.61 (d, $J=7.6 \mathrm{~Hz}, 6 \mathrm{H}$, ortho protons). ${ }^{13} \mathrm{C}$ NMR $\left(100.6 \mathrm{MHz}, \mathrm{THF}-d_{8}\right): \delta$ $10.1,19.0$ (t, $J=12.2 \mathrm{~Hz}), 91.7,128.14,128.22,129.5,145.9 .{ }^{31} \mathrm{P}$ NMR $\left(161.9 \mathrm{MHz}, \mathrm{THF}-d_{8}\right): \delta$ $34.5\left(\mathrm{~d}, J_{\mathrm{PRh}}=210 \mathrm{~Hz}\right.$ ). Anal. Calcd for $\mathrm{C}_{31} \mathrm{H}_{45} \mathrm{OP}_{2} \mathrm{Rh}$ : C, 62.21; H, 7.58. Found: C, 62.03; H, 7.79.

Preparation of $\left(\mathbf{P E t}_{3}\right)_{2} \mathbf{R h O R}(\mathbf{R}=9$-phenyl-9-xanthenyl, 2c). The general procedure for the preparation of bis(triethylphosphine)-ligated rhodium alkoxide complexes, followed by crystallization from $\mathrm{Et}_{2} \mathrm{O}$ at $-35{ }^{\circ} \mathrm{C}$, gave dark-brown crystals of $2 \mathrm{c}$ (162 $\mathrm{mg}, 66 \%$ yield). ${ }^{1} \mathrm{H}$ NMR (400 MHz, $\left.\mathrm{C}_{6} \mathrm{D}_{6}\right): \delta 0.80-1.00\left(\mathrm{~m}, 18 \mathrm{H}, \mathrm{CH}_{3}\right.$ signals for the $\mathrm{PEt}_{3}$ ligands), 1.10-1.20 (m, $12 \mathrm{H}, \mathrm{CH}_{2}$ signals for the $\mathrm{PEt}_{3}$ ligands), $6.86(\mathrm{t}, J=6.7 \mathrm{~Hz}, 1 \mathrm{H}), 6.90-7.00(\mathrm{~m}, 4 \mathrm{H}), 7.07(\mathrm{t}, J=7.2$ $\mathrm{Hz}, 2 \mathrm{H}), 7.21(\mathrm{~d}, J=7.2 \mathrm{~Hz}, 2 \mathrm{H}), 7.70(\mathrm{~d}, J=7.0 \mathrm{~Hz}, 2 \mathrm{H}), 8.28$ (brd. s, 2H). ${ }^{13} \mathrm{C}$ NMR (125.8 MHz, THF- $\left.d_{8}, 0{ }^{\circ} \mathrm{C}\right): \delta 10.2,18.9(\mathrm{t}, J=12.3 \mathrm{~Hz}), 77.4,116.9,120.1,123.5,126.0,127.2,129.4$, 
130.1, 130.4, 154.9, 157.2. ${ }^{31} \mathrm{P}$ NMR $\left(161.9 \mathrm{MHz}, \mathrm{C}_{6} \mathrm{D}_{6}\right): \delta 33.7\left(\mathrm{~d}, J_{\mathrm{PRh}}=208 \mathrm{~Hz}\right)$. Anal. Calcd for $\mathrm{C}_{31} \mathrm{H}_{43} \mathrm{O}_{2} \mathrm{P}_{2} \mathrm{Rh}: \mathrm{C}, 60.79 ; \mathrm{H}, 7.08$. Found: C, 60.56; H, 7.07.

General Procedure for the Generation and in situ NMR Characterization of Unstable Bis(triethylphosphine) $\mathbf{R h}(\mathbf{I})$ Alkoxides (2b, 2d). Into a small vial equipped with a magnetic stir bar was placed $\left(\mathrm{PEt}_{3}\right)_{2} \mathrm{RhN}\left(\mathrm{SiMe}_{3}\right)_{2}(50 \mathrm{mg}, 0.10 \mathrm{mmol})$. The corresponding tertiary alcohol ( $0.10 \mathrm{mmol}, 1.0$ equiv) was dissolved in THF- $d_{8}(0.5 \mathrm{~mL})$ and added dropwise. The resulting solution was stirred briefly at room temperature $(<2 \mathrm{~min})$ before being transferred to a thick-walled NMR tube equipped with a screw cap and a Teflon seal. The subsequent NMR characterization was carried out at low temperatures to avoid decomposition.

Generation and in situ NMR Characterization of $\left(\mathrm{PEt}_{3}\right)_{2} \mathbf{R h O C}(\mathrm{Me}) \mathrm{Ph}_{2}(\mathbf{2 b})$. The general procedure for generation of unstable bis(triethylphosphine) $\mathrm{Rh}(\mathrm{I})$ alkoxides gave a dark brown solution of $\mathbf{2 b} .{ }^{1} \mathrm{H}$ NMR (400 MHz, THF- $\left.d_{8},-20{ }^{\circ} \mathrm{C}\right): \delta 1.03-1.12\left(\mathrm{~m}, 18 \mathrm{H}, \mathrm{CH}_{3}\right.$ signals for the $\mathrm{PEt}_{3}$ ligands), $1.25-1.35\left(\mathrm{~m}, 12 \mathrm{H}, \mathrm{CH}_{2}\right.$ signals for the $\mathrm{PEt}_{3}$ ligands), 1.96 (s, $3 \mathrm{H}, \mathrm{CH}_{3}$ signal for the alkoxo ligand), $7.01(\mathrm{t}, J=7.3 \mathrm{~Hz}, 1 \mathrm{H}$, para proton), $7.20(\mathrm{t}, J=7.7 \mathrm{~Hz}, 2 \mathrm{H}$, meta protons), 7.68 (brd d, $J=6.0 \mathrm{~Hz}, 2 \mathrm{H}$, ortho protons). ${ }^{13} \mathrm{C}$ NMR $\left(100.6 \mathrm{MHz}, \mathrm{THF}-d_{8},-20{ }^{\circ} \mathrm{C}\right): \delta$ $10.5,18.6(\mathrm{t}, J=12.2 \mathrm{~Hz}), 36.2,82.8,124.1,128.3,130.8,143.4 .{ }^{31} \mathrm{P}$ NMR $\left(161.9 \mathrm{MHz}\right.$, THF- $d_{8}$, $\left.-20{ }^{\circ} \mathrm{C}\right): \delta 36.4\left(\mathrm{~d}, J_{\mathrm{PRh}}=207.6 \mathrm{~Hz}\right)$.

Generation and in situ NMR Characterization of $\left(\mathrm{PEt}_{3}\right)_{2} \mathrm{RhOR}$ (R=9-phenyl-9fluorenyl, 2d). The general procedure for generation of unstable bis(triethylphosphine) $\mathrm{Rh}(\mathrm{I})$ alkoxides gave a dark maroon solution of $\mathbf{2 d} .{ }^{1} \mathrm{H}$ NMR (400 MHz, THF- $\left.d_{8},-20{ }^{\circ} \mathrm{C}\right): \delta$ 0.95-1.05 (m, $18 \mathrm{H}, \mathrm{CH}_{3}$ signals for the $\mathrm{PEt}_{3}$ ligands), 1.25-1.32 (m, 12H, $\mathrm{CH}_{2}$ signals for the $\mathrm{PEt}_{3}$ ligands), $7.07(\mathrm{t}, J=7.4 \mathrm{~Hz}, 1 \mathrm{H}), 7.13-7.24(\mathrm{~m}, 6 \mathrm{H}), 7.60-7.65(\mathrm{~m}, 4 \mathrm{H}), 7.84(\mathrm{~d}, J=7.1 \mathrm{~Hz}, 2 \mathrm{H}) .{ }^{13} \mathrm{C} \mathrm{NMR}$ (100.6 MHz, THF- $\left.d_{8},-20{ }^{\circ} \mathrm{C}\right): \delta 10.4,18.9$ (t, $\left.J=12.4 \mathrm{~Hz}\right), 94.1,121.5,123.98,124.13,129.3$, 
129.67, 129.82, 131.2, 141.3, 142.4, 151.9. ${ }^{31} \mathrm{P}$ NMR $\left(161.9 \mathrm{MHz}, \mathrm{THF}-d_{8},-20{ }^{\circ} \mathrm{C}\right): \delta 36.9(\mathrm{~d}$, $\left.J_{\mathrm{PRh}}=211.1 \mathrm{~Hz}\right)$.

General Procedure for the Preparation of Tris(triethylphosphine) Rh(I) Alkoxides (3b-3e). Into a $20 \mathrm{~mL}$ scintillation vial equipped with a magnetic stir bar was placed $\left(\mathrm{PEt}_{3}\right)_{2} \mathrm{RhN}\left(\mathrm{SiMe}_{3}\right)_{2}(200 \mathrm{mg}, 0.40 \mathrm{mmol}), \mathrm{PEt}_{3}\left(95 \mathrm{mg}, 0.80 \mathrm{mmol}, 2.0\right.$ equiv) and $\mathrm{Et}_{2} \mathrm{O}(5 \mathrm{~mL})$. The mixture was stirred at room temperature for $5 \mathrm{~min}$. The corresponding tertiary alcohol $(0.40$ mmol, 1.0 equiv) was dissolved in $\mathrm{Et}_{2} \mathrm{O}(2 \mathrm{~mL})$ and added dropwise while stirring. An instant color change from dark purple to bright orange or brown was observed. The solution was stirred at room temperature for 5-15 min until the rhodium silylamide was fully converted, as determined by ${ }^{31} \mathrm{P}$ NMR spectroscopy. Evaporation of the volatile materials removed under reduced pressure afforded the crude rhodium alkoxide products as powders (3b-3d) or sticky gels (3e). Further purification was achieved by crystallization from $\mathrm{Et}_{2} \mathrm{O}$ in the presence of added $\mathrm{PEt}_{3}$ at $-35{ }^{\circ} \mathrm{C}(\mathbf{3 c}, 3 \mathbf{d})$, or washing repeatedly with cold pentane that contained a small amount of added $\mathrm{PEt}_{3}$ to minimize ligand dissociation before drying in vacuo $(\mathbf{3 b}, \mathbf{3 e})$. In solution, $\mathbf{3 b} \mathbf{b}-\mathbf{3 e}$ spontaneously release $\mathrm{PEt}_{3}$ to generate an equilibrium mixture of the tris(triethylphosphine) complexes and their bis(triethylphosphine) counterparts. For this reason, NMR spectra of these complexes were obtained on solutions containing an excess of added $\mathrm{PEt}_{3}(\sim 5$ equiv).

Preparation of $\left(\mathbf{P E t}_{3}\right)_{3} \mathbf{R h O C}(\mathrm{Me}) \mathbf{P h}_{2}(3 \mathrm{~b})$. The general procedure for the preparation of tris(triethylphosphine)-ligated rhodium alkoxide complexes, followed by washing with cold pantane in the presence of added $\mathrm{PEt}_{3}$ and drying in vacuo, gave $\mathbf{3 b}$ as orange powders $(217 \mathrm{mg}$, $84 \%$ yield). The stability of this complex at room temperature was limited, and it was stored at $35{ }^{\circ} \mathrm{C}$. Although the analytical data for most of the alkoxide complexes in this work was acceptable and the spectral data of this complex indicated similar purity, suitable analytical data 
were not obtained on this complex. NMR spectra are provided below to demonstrate purity (Figures S2-S4). These NMR spectroscopic characterizations were carried out in the presence of added $\mathrm{PEt}_{3}$ to suppress $\mathrm{PEt}_{3}$ dissociation. ${ }^{1} \mathrm{H}$ NMR $\left(400 \mathrm{MHz}\right.$, THF- $d_{8},-20{ }^{\circ} \mathrm{C}$; assignments of the ${ }^{1} \mathrm{H}$ NMR signals are provided here for $\mathbf{3 b}$ and are analogous for the other trisphosphine alkoxide complexes 3c-3e): $\delta$ 1.08-1.20 $\left(\mathrm{m}, 12 \mathrm{H}, \mathrm{CH}_{3}\right.$ signals for the $\mathrm{PEt}_{3}$ ligand trans to the alkoxy ligand), 1.45-1.52 (m, $18 \mathrm{H}, \mathrm{CH}_{2}$ signals for the $\mathrm{PEt}_{3}$ ligands), 2.51 (s, $3 \mathrm{H}, \mathrm{CH}_{3}$ signal for the alkoxo ligand), $6.88(\mathrm{t}, J=7.2 \mathrm{~Hz}, 1 \mathrm{H}$, para proton), 7.03 (t, J=7.6 Hz, 2H, meta protons), 7.58 (d, J=7.2 Hz, 2H, ortho protons). $\mathrm{CH}_{3}$ signals for the cis $\mathrm{PEt}_{3}$ ligands were not observed due to overlapping with $\mathrm{CH}_{3}$ signals for unbound $\mathrm{PEt}_{3}$ (multiplets at around 0.9-1.1 ppm). ${ }^{13} \mathrm{C} \mathrm{NMR}$ (100.6 MHz, THF- $\left.d_{8},-20{ }^{\circ} \mathrm{C}\right): \delta 10.4,11.2,19.0(\mathrm{t}, J=10.0 \mathrm{~Hz}), 23.8(\mathrm{~d}, J=24.0 \mathrm{~Hz}), 32.4,80.8$, 126.0, 128.7, 129.0, 159.7. ${ }^{31} \mathrm{P}$ NMR (161.9 MHz, THF- $\left.d_{8},-20{ }^{\circ} \mathrm{C}\right): \delta 15.1\left(\mathrm{dd}, J_{\mathrm{PRh}}=150 \mathrm{~Hz}\right.$, $\left.J_{\mathrm{PP}}=44 \mathrm{~Hz}\right), 38.4\left(\mathrm{dt}, J_{\mathrm{PRh}}=164 \mathrm{~Hz}, J_{\mathrm{PP}}=44 \mathrm{~Hz}\right)$.

Preparation of $\left(\mathbf{P E t}_{3}\right)_{3} \mathbf{R h O R}(\mathbf{R}=9$-phenyl-9-xanthenyl, 3c). The general procedure for the preparation of tris(triethylphosphine)-ligated rhodium alkoxide complexes, followed by recrystallization from cold $\mathrm{Et}_{2} \mathrm{O}$ in the presence of added $\mathrm{PEt}_{3}$, gave orange crystals of $\mathbf{3 c}$ (225 mg, 77\% yield). NMR spectroscopic characterizations were carried out in the presence of $\sim 5$ equiv added $\mathrm{PEt}_{3}$ to suppress $\mathrm{PEt}_{3}$ dissociation. ${ }^{1} \mathrm{H} \mathrm{NMR}\left(400 \mathrm{MHz}, \mathrm{THF}-d_{8},-20{ }^{\circ} \mathrm{C}\right): \delta 0.79-$ $0.90(\mathrm{~m}, 18 \mathrm{H}), 1.05-1.15\left(\mathrm{~m}, 9 \mathrm{H}\right.$, overlapping with $\mathrm{CH}_{3}$ signals for unbound $\left.\mathrm{PEt}_{3}\right), 1.35-1.58(\mathrm{~m}$, 18H, partial overlapping with $\mathrm{CH}_{2}$ signals for unbound $\left.\mathrm{PEt}_{3}\right), 6.80(\mathrm{t}, \mathrm{J}=6.9 \mathrm{~Hz}, 1 \mathrm{H}), 6.85-6.95$ (m, 4H), $6.98(\mathrm{~d}, J=7.6 \mathrm{~Hz}, 2 \mathrm{H}), 7.05-7.18(\mathrm{~m}, 4 \mathrm{H}), 9.33$ (brd. d, $J=6.7 \mathrm{~Hz}, 2 \mathrm{H}) .{ }^{13} \mathrm{C}$ NMR $(125.8$ MHz, THF- $\left.d_{8},-20{ }^{\circ} \mathrm{C}\right): \delta 10.1,11.2,19.3(\mathrm{t}, J=10.0 \mathrm{~Hz}), 24.1(\mathrm{~d}, J=25.2 \mathrm{~Hz}), 77.6,116.5,124.0$, $126.4,128.71,128.75,129.5,131.1,137.9,152.4,159.2 .{ }^{31} \mathrm{P}$ NMR $\left(161.9 \mathrm{MHz}, \mathrm{THF}-d_{8},-20\right.$ 
$\left.{ }^{\circ} \mathrm{C}\right): \delta 14.1\left(\mathrm{dd}, J_{\mathrm{PRh}}=150 \mathrm{~Hz}, J_{\mathrm{PP}}=45 \mathrm{~Hz}\right), 41.8\left(\mathrm{dt}, J_{\mathrm{PRh}}=167 \mathrm{~Hz}, J_{\mathrm{PP}}=45 \mathrm{~Hz}\right)$. Anal. Calcd for $\mathrm{C}_{37} \mathrm{H}_{58} \mathrm{O}_{2} \mathrm{P}_{3} \mathrm{Rh}: \mathrm{C}, 60.82 ; \mathrm{H}, 8.00$. Found: $\mathrm{C}, 60.53 ; \mathrm{H}, 8.05$.

Preparation of $\left(\mathbf{P E t}_{3}\right)_{3} \mathbf{R h O R}(\mathbf{R}=9$-phenyl-9-fluorenyl, 3d). The general procedure for the preparation of tris(triethylphosphine)-ligated rhodium alkoxide complexes, followed by recrystallization from cold $\mathrm{Et}_{2} \mathrm{O}$ in the presence of added $\mathrm{PEt}_{3}$, gave orange crystals of $\mathbf{3 d}$ (252 mg, $88 \%$ yield). NMR spectroscopic characterizations were carried out in the presence of $\sim 5$ equiv added $\mathrm{PEt}_{3}$ to suppress $\mathrm{PEt}_{3}$ dissociation. ${ }^{1} \mathrm{H} \mathrm{NMR}\left(400 \mathrm{MHz}, \mathrm{THF}-d_{8},-20{ }^{\circ} \mathrm{C}\right): \delta 0.85-$ 0.95 (m, 18H, $\mathrm{CH}_{3}$ signals for the cis $\mathrm{PEt}_{3}$ ligands), 0.95-1.05 (m, 9H, partial overlapping with $\mathrm{CH}_{3}$ signals for unbound $\left.\mathrm{PEt}_{3}\right), 1.35-1.50\left(\mathrm{~m}, 18 \mathrm{H}\right.$, partial overlapping with $\mathrm{CH}_{2}$ signals for unbound $\left.\mathrm{PEt}_{3}\right), 6.89$ (t, J=7.5 Hz, 1H), $6.95(\mathrm{t}, J=7.1 \mathrm{~Hz}, 2 \mathrm{H}), 7.10-7.15(\mathrm{~m}, 4 \mathrm{H}), 7.32(\mathrm{~d}, J=7.6$ $\mathrm{Hz}, 2 \mathrm{H}), 7.52(\mathrm{~d}, J=6.7 \mathrm{~Hz}, 2 \mathrm{H}), 8.15(\mathrm{~d}, J=6.4 \mathrm{~Hz}, 2 \mathrm{H}) .{ }^{13} \mathrm{C}$ NMR $\left(100.6 \mathrm{MHz}, \mathrm{THF}-d_{8},-20\right.$ $\left.{ }^{\circ} \mathrm{C}\right): \delta 10.3,11.2,19.3(\mathrm{t}, J=10.0 \mathrm{~Hz}), 23.9(\mathrm{~d}, J=24.6 \mathrm{~Hz}), 92.4,120.9,126.9,127.4,128.55$, 128.57, 128.66, 129.7, 141.6, 157.5, 160.5. ${ }^{31} \mathrm{P}$ NMR (161.9 MHz, THF- $\left.d_{8},-20{ }^{\circ} \mathrm{C}\right): \delta 12.8(\mathrm{dd}$, $\left.J_{\mathrm{PRh}}=151 \mathrm{~Hz}, J_{\mathrm{PP}}=44 \mathrm{~Hz}\right), 39.3\left(\mathrm{dt}, J_{\mathrm{PRh}}=165 \mathrm{~Hz}, J_{\mathrm{PP}}=44 \mathrm{~Hz}\right)$. Anal. Calcd for $\mathrm{C}_{37} \mathrm{H}_{58} \mathrm{OP}_{3} \mathrm{Rh}: \mathrm{C}$, 62.18; H, 8.18. Found: C, 61.92; H, 8.33.

Preparation of $\left(\mathbf{P E t}_{3}\right)_{3} \mathbf{R h O C}\left(\mathrm{CF}_{3}\right) \mathbf{M e}_{2}(3 \mathrm{e})$. The general procedure for the preparation of tris(triethylphosphine)-ligated rhodium alkoxide complexes, followed by washing with cold pantane in the presence of added $\mathrm{PEt}_{3}$ and drying in vacuo, gave $\mathbf{3 e}$ as sticky brown powders (213 mg, 91\% yield). ). This complex also showed limited stability and needed to be stored at low temperature $\left(-35^{\circ} \mathrm{C}\right)$. Suitable analytical data were not obtained on this complex and NMR spectra are provided below to demonstrate purity (see Figure S5-S8). These NMR spectroscopic characterizations were carried out in the presence of added $\mathrm{PEt}_{3}$ to suppress $\mathrm{PEt}_{3}$ dissociation. ${ }^{1} \mathrm{H}$ NMR (400 MHz, THF- $\left.d_{8},-20{ }^{\circ} \mathrm{C}\right): \delta 1.00-1.15\left(\mathrm{~m}, 27 \mathrm{H}, \mathrm{CH}_{3}\right.$ signals for the $\mathrm{PEt}_{3}$ ligands), $1.40-$ 
$1.52\left(\mathrm{~m}, 6 \mathrm{H}, \mathrm{CH}_{2}\right.$ signals for the trans $\mathrm{PEt}_{3}$ ligands), 1.60-1.72 (m, $12 \mathrm{H}, \mathrm{CH}_{2}$ signals for the cis $\mathrm{PEt}_{3}$ ligands). ${ }^{13} \mathrm{C}$ NMR $\left(100.6 \mathrm{MHz}, \mathrm{THF}-d_{8},-20{ }^{\circ} \mathrm{C}\right): \delta 6.5,7.0,15.6(\mathrm{t}, J=10.1 \mathrm{~Hz}), 19.3(\mathrm{~d}$, $J=23.7 \mathrm{~Hz}$ ), 26.1, 72.6 (quartet, $J=24.5 \mathrm{~Hz}$ ), 127.7 (quartet, $J=293 \mathrm{~Hz}$ ). ${ }^{31} \mathrm{P} \mathrm{NMR}(161.9 \mathrm{MHz}$, THF $\left.-d_{8},-20{ }^{\circ} \mathrm{C}\right): \delta 10.0\left(\mathrm{dd}, J_{\mathrm{PRh}}=153 \mathrm{~Hz}, J_{\mathrm{PP}}=45 \mathrm{~Hz}\right), 33.3\left(\mathrm{dt}, J_{\mathrm{PRh}}=160 \mathrm{~Hz}, J_{\mathrm{PP}}=45 \mathrm{~Hz}\right) .{ }^{19} \mathrm{~F}$ NMR (376.4 MHz, THF- $\left.d_{8},-20{ }^{\circ} \mathrm{C}\right): \delta$-80.4.

\section{General Procedure for the $\beta$-Phenyl Eliminations of $\mathbf{R h}(\mathbf{I})$ Alkoxide Complexes 2a}

and 3b-3d. Into a small vial was placed the rhodium alkoxide complex (0.010 $\mathrm{mmol}, \mathrm{PEt}_{3}$ ( 0.020 or $0.10 \mathrm{mmol}$ ) and $1.0 \mathrm{mg}$ of 1,3,5-trimethoxybenzene as internal standard. $\mathrm{C}_{6} \mathrm{D}_{6}$ or $\mathrm{C}_{6} \mathrm{D}_{12}$ $(0.7 \mathrm{~mL})$ was added, and the solution was stirred until it was homogeneous before being transferred to a thick-walled NMR tube equipped with a screw cap and a Teflon seal. An initial ${ }^{1} \mathrm{H}$ NMR spectrum was acquired. The solution was then heated in a thermostated oil bath at 50$80{ }^{\circ} \mathrm{C}$ for $20 \mathrm{~min}-20 \mathrm{~h}$ until the starting rhodium complex was fully consumed, as determined by ${ }^{1} \mathrm{H}$ or ${ }^{31} \mathrm{P}$ NMR spectroscopy. A second ${ }^{1} \mathrm{H}$ NMR spectrum was acquired, and the yield of the ketone and the rhodium phenyl product $\left(\mathrm{PEt}_{3}\right)_{3} \mathrm{RhPh}(4)$ were calculated.

$\boldsymbol{\beta}$-Phenyl Elimination of $\left.\left(\mathbf{P E t}_{\mathbf{3}}\right)_{\mathbf{2}} \mathbf{R h O C P h} \mathbf{3} \mathbf{2 a}\right)$. The reaction of $\mathbf{2 a}(6.0 \mathrm{mg}, 0.010$

mmol) with added $\mathrm{PEt}_{3}(2.4 \mathrm{mg}, 0.020 \mathrm{mmol}, 2.0$ equiv) and 1,3,5-trimethoxybenzene as internal standard in $\mathrm{C}_{6} \mathrm{D}_{6}(0.7 \mathrm{~mL})$ at $50{ }^{\circ} \mathrm{C}$ for $1 \mathrm{~h}$ gave $68 \%$ yield of $\left(\mathrm{PEt}_{3}\right)_{3} \mathrm{RhPh}(4)$ and $62 \%$ yield of benzophenone (5a), as determined by ${ }^{1} \mathrm{H}$ NMR spectroscopy.

$\boldsymbol{\beta}$-Phenyl Elimination of $\left(\mathbf{P E t}_{\mathbf{3}}\right)_{\mathbf{3}} \mathbf{R h O C}(\mathbf{M e}) \mathbf{P h}_{\mathbf{2}}(\mathbf{3 b})$. The reaction of $\mathbf{3 b}(6.5 \mathrm{mg}, 0.010$ mmol) with added $\mathrm{PEt}_{3}(2.4 \mathrm{mg}, 0.020 \mathrm{mmol}, 2.0$ equiv) and 1,3,5-trimethoxybenzene as internal standard in $\mathrm{C}_{6} \mathrm{D}_{6}(0.7 \mathrm{~mL})$ at $50{ }^{\circ} \mathrm{C}$ for $1 \mathrm{~h}$ gave $61 \%$ yield of $\left(\mathrm{PEt}_{3}\right)_{3} \mathrm{RhPh}(4)$ and $57 \%$ yield of acetophenone (5b) with a half-life of about $15 \mathrm{~min}$, as determined by ${ }^{1} \mathrm{H}$ NMR spectroscopy. 
When the same reaction was carried out with 10 equiv of added $\mathrm{PEt}_{3}$, lower yields $(56 \%$ of 4 and $50 \%$ of $\mathbf{5 b}$ ) were measured and the reaction rate constant was smaller (half-life $\sim 30 \mathrm{~min}$ ).

$\beta$-Phenyl Elimination of $\left(\mathbf{P E t}_{3}\right)_{3} \mathbf{R h O R}(\mathbf{R}=9$-phenyl-9-xanthenyl, $3 c)$. The reaction of 3c (7.3 mg, $0.010 \mathrm{mmol})$ with added $\mathrm{PEt}_{3}(2.4 \mathrm{mg}, 0.020 \mathrm{mmol}, 2.0$ equiv) and 1,3,5trimethoxybenzene as internal standard in $\mathrm{C}_{6} \mathrm{D}_{6}(0.7 \mathrm{~mL})$ at $50{ }^{\circ} \mathrm{C}$ for 20 min gave $>95 \%$ yield of $\left(\mathrm{PEt}_{3}\right)_{3} \mathrm{RhPh}(\mathbf{4})$ and $62 \%$ yield of xanthone (5c), as determined by ${ }^{1} \mathrm{H}$ NMR spectroscopy. When the same reaction was carried out with 10 equiv of added $\mathrm{PEt}_{3}$, lower yields $(63 \%$ of $\mathbf{4}$ and $37 \%$ of 5c; about $40 \%$ of 9-phenyl-9-xanthenol (1c) was also detected as the major byproduct) were measured, and the reaction rate constant was smaller (half-life $\sim 10 \mathrm{~min}$ ). The same reaction was also carried out at $40{ }^{\circ} \mathrm{C}$ in $\mathrm{C}_{6} \mathrm{D}_{6}$. Higher yields from $\beta$-phenyl elimination, as well as higher reaction rates were observed for the reations conducted with less added $\mathrm{PEt}_{3}:>95 \%$ of $\mathbf{4}$ and $61 \%$ of $\mathbf{5 c}$ with a half-life of 20 min with 2 equiv of added $\mathrm{PEt}_{3} ; 33 \%$ of $\mathbf{4}, 32 \%$ of $\mathbf{5 c}$ and $66 \%$ of 1c with a half-life of 50 min with 10 equiv of added $\mathrm{PEt}_{3}$.

$\beta$-Phenyl Elimination of $\left(\mathbf{P E t}_{3}\right)_{3} \mathbf{R h O R}(\mathbf{R}=9$-phenyl-9-fluorenyl, 3d). The reaction of 3d (7.1 mg, $0.010 \mathrm{mmol})$ with added $\mathrm{PEt}_{3}(2.0 \mathrm{mg}, 0.020 \mathrm{mmol}, 2.0$ equiv) and 1,3,5trimethoxybenzene as internal standard in $\mathrm{C}_{6} \mathrm{D}_{12}(0.7 \mathrm{~mL})$ at $80{ }^{\circ} \mathrm{C}$ for 30 min gave $80 \%$ yield of $\left(\mathrm{PEt}_{3}\right)_{3} \mathrm{RhPh}(\mathbf{4})$ and $83 \%$ yield of fluorenone (5d) with a half-life of about 4 min, as determined by ${ }^{1} \mathrm{H}$ NMR spectroscopy. When the same reaction was carried out with 10 equiv of added $\mathrm{PEt}_{3}$, lower yields ( $27 \%$ of $\mathbf{4}$ and $31 \%$ of $\mathbf{5 d}$ ) were measured, and the reaction rate constant was smaller (half-life $\sim 10 \mathrm{~min}$ ). When the reaction with 2.0 amount of $\mathrm{PEt}_{3}$ was carried out at $50{ }^{\circ} \mathrm{C}$, only $17 \%$ of $\mathbf{4}$ and $25 \%$ of $\mathbf{5 d}$ were acquired with a half-life of about 7 h. The same reaction was also carried out at $70{ }^{\circ} \mathrm{C}$ in $\mathrm{C}_{6} \mathrm{D}_{12}$. Higher yields of products from $\beta$-phenyl elimination, as well as higher reaction rates were observed for the reactions conducted with less added $\mathrm{PEt}_{3}: 82 \%$ of 
4 and $76 \%$ of $\mathbf{5 d}$ with a half-life of 30 min with 2 equiv of added $\mathrm{PEt}_{3} ; 27 \%$ of $\mathbf{4}, 27 \%$ of $\mathbf{5 d}$ and $\sim 80 \%$ of 9-phenyl-9-fluorenol (1d) with a half-life of 65 min with 10 equiv of added $\mathrm{PEt}_{3}$. Representative Procedure for the Kinetic Experiments Conducted on $\beta$-Phenyl Elimination of $\left(\mathrm{PEt}_{3}\right)_{2} \mathrm{RhOCPh}_{3}(\mathbf{2 a})$ in the Presence of Added $\mathbf{P E t}_{3}$. Into a small vial was placed complex $2 \mathrm{a}(6.0 \mathrm{mg}, 0.010 \mathrm{mmol})$ and $1.0 \mathrm{mg}$ of 1,3,5-trimethoxybenzene. $\mathrm{C}_{6} \mathrm{D}_{6}(0.70$ $\mathrm{mL}$ ) and $\mathrm{PEt}_{3}(2.4 \mathrm{mg}, 0.020 \mathrm{mmol}, 2.0$ equiv) were added by syringe. The mixture was stirred at room temperature until it was homogeneous. The solution was transferred to an NMR tube equipped with a screw cap and a Teflon seal. The sample was placed into a thermostated oil bath at $60{ }^{\circ} \mathrm{C}$ to start the reaction, and a ${ }^{1} \mathrm{H}$ NMR spectrum was obtained at fixed intervals. This procedure was repeated using different initial concentrations of $\mathrm{PEt}_{3}$ with and without added benzophenone (5a). 


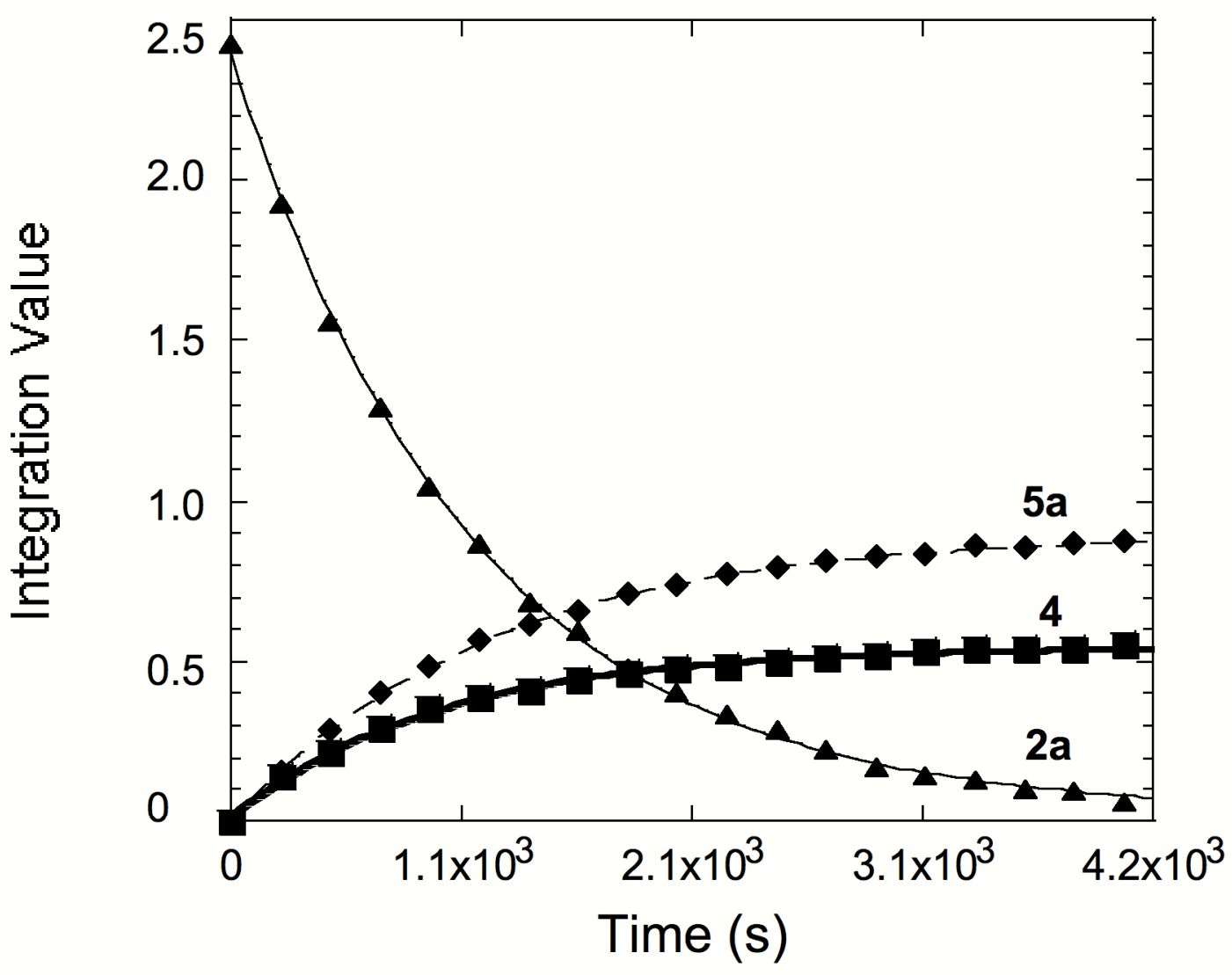

Figure S1. Representative kinetic plot for the $\beta$-phenyl elimination of rhodium alkoxide complex 2a $(0.014 \mathrm{M})$ in the presence of $\operatorname{PEt}_{3}(0.070 \mathrm{M})$ in $\mathrm{C}_{6} \mathrm{D}_{6}$ at $50{ }^{\circ} \mathrm{C}$. The curve for the consumption of $\mathbf{2 a}$ depicts the results of an unweighted least-square fit to $y=a^{*} \exp \left(-b^{*} x\right)+c(a$ $=2.37 \pm 0.01, \mathrm{~b}=0.00093 \pm 0.00002, \mathrm{c}=0.03 \pm 0.01)$. The curve for the accumulation of $\left(\mathrm{PEt}_{3}\right)_{3} \mathrm{RhPh}(4)$ depicts the results of an unweighted least-square fit to $\mathrm{y}=-\mathrm{a}^{*} \exp \left(-\mathrm{b}^{*} \mathrm{x}\right)+\mathrm{c}(\mathrm{a}=$ $0.531 \pm 0.007, b=0.00106 \pm 0.00004, c=0.547 \pm 0.005)$. The curve for the accumulation of benzophenone (5a) depicts the results of an unweighted least-square fit to $y=-a^{*} \exp \left(-b^{*} x\right)+c$ $(\mathrm{a}=1.00 \pm 0.01, \mathrm{~b}=0.00076 \pm 0.00002, \mathrm{c}=1.01 \pm 0.01)$. The differences between the integration values are due to the ortho proton signal intensities used for integration: $6 \mathrm{H}$ for $\mathbf{2 a}$, $2 \mathrm{H}$ for $\mathbf{4}$ and $4 \mathrm{H}$ for $\mathbf{5 a}$. 
References

1) Van der Ent, A.; Onderdelinden, A. L. Inorg. Syn. 1973, 14, 92.

2) Zhao, P.; Krug, C.; Hartwig, J. F. J. Am. Chem. Soc. 2005, 127, 12066.

3) Zhao, P.; Hartwig, J. F. J. Am. Chem. Soc. 2005, 127, 11618. 

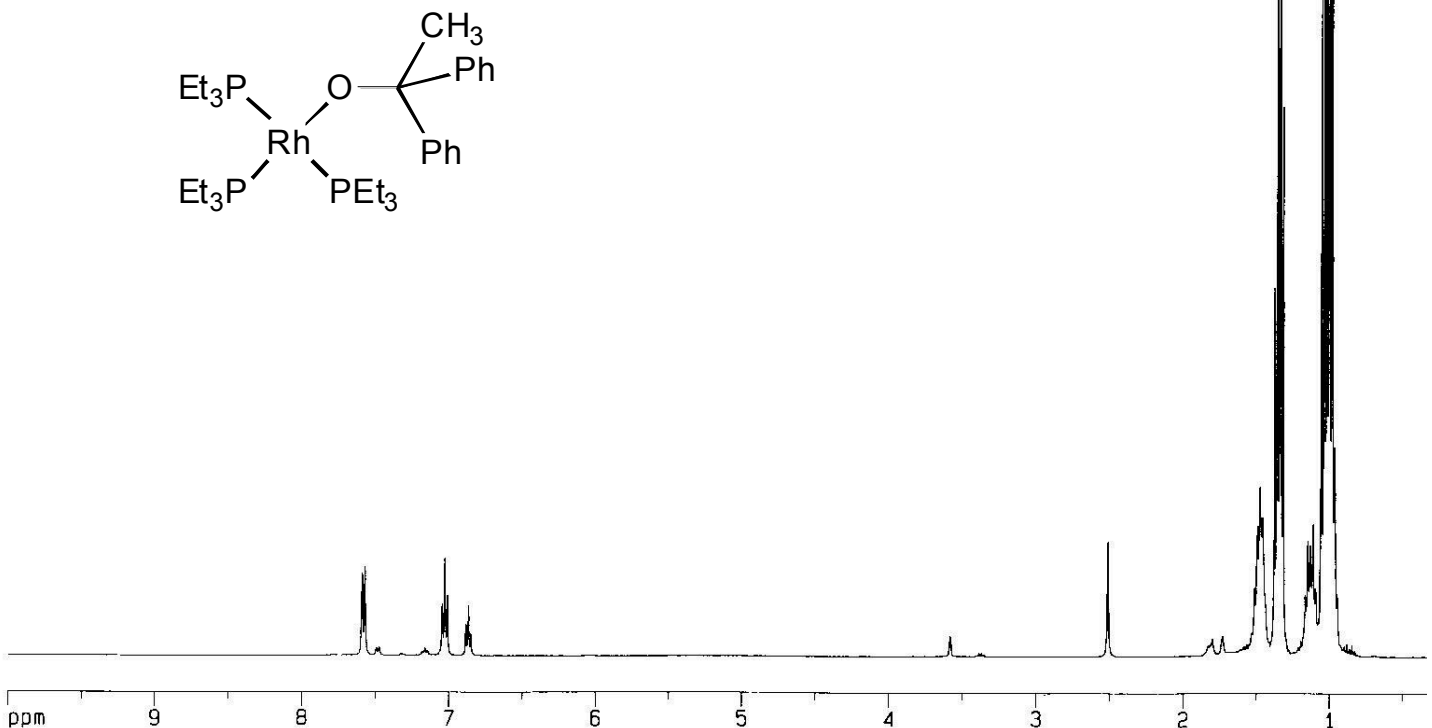

Figure S2. ${ }^{1} \mathrm{H}$ NMR spectrum $\left(400 \mathrm{MHz}, \mathrm{THF}-d_{8},-20{ }^{\circ} \mathrm{C}\right)$ of $\left(\mathrm{PEt}_{3}\right)_{3} \mathrm{RhOC}(\mathrm{Me}) \mathrm{Ph}_{2}(3 \mathbf{b})$ in the presence of added $\mathrm{PEt}_{3}(\sim 5$ equiv $)$. 


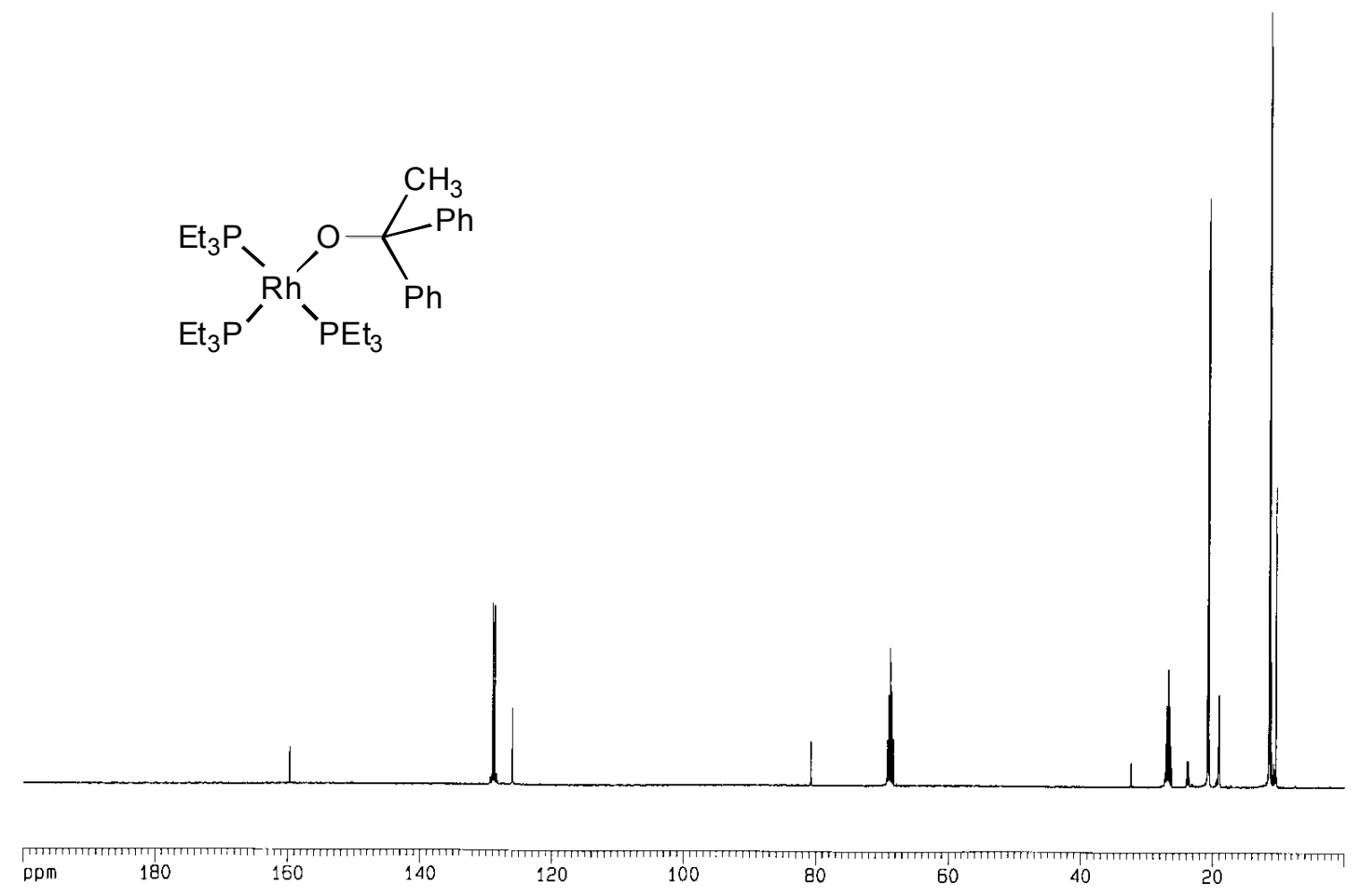

Figure S3. ${ }^{13} \mathrm{C}$ NMR spectrum $\left(100.6 \mathrm{MHz}\right.$, THF- $\left.d_{8},-20{ }^{\circ} \mathrm{C}\right)$ of $\left(\mathrm{PEt}_{3}\right)_{3} \mathrm{RhOC}(\mathrm{Me}) \mathrm{Ph}_{2}(3 \mathbf{b})$ in the presence of added $\mathrm{PEt}_{3}(\sim 5$ equiv). 

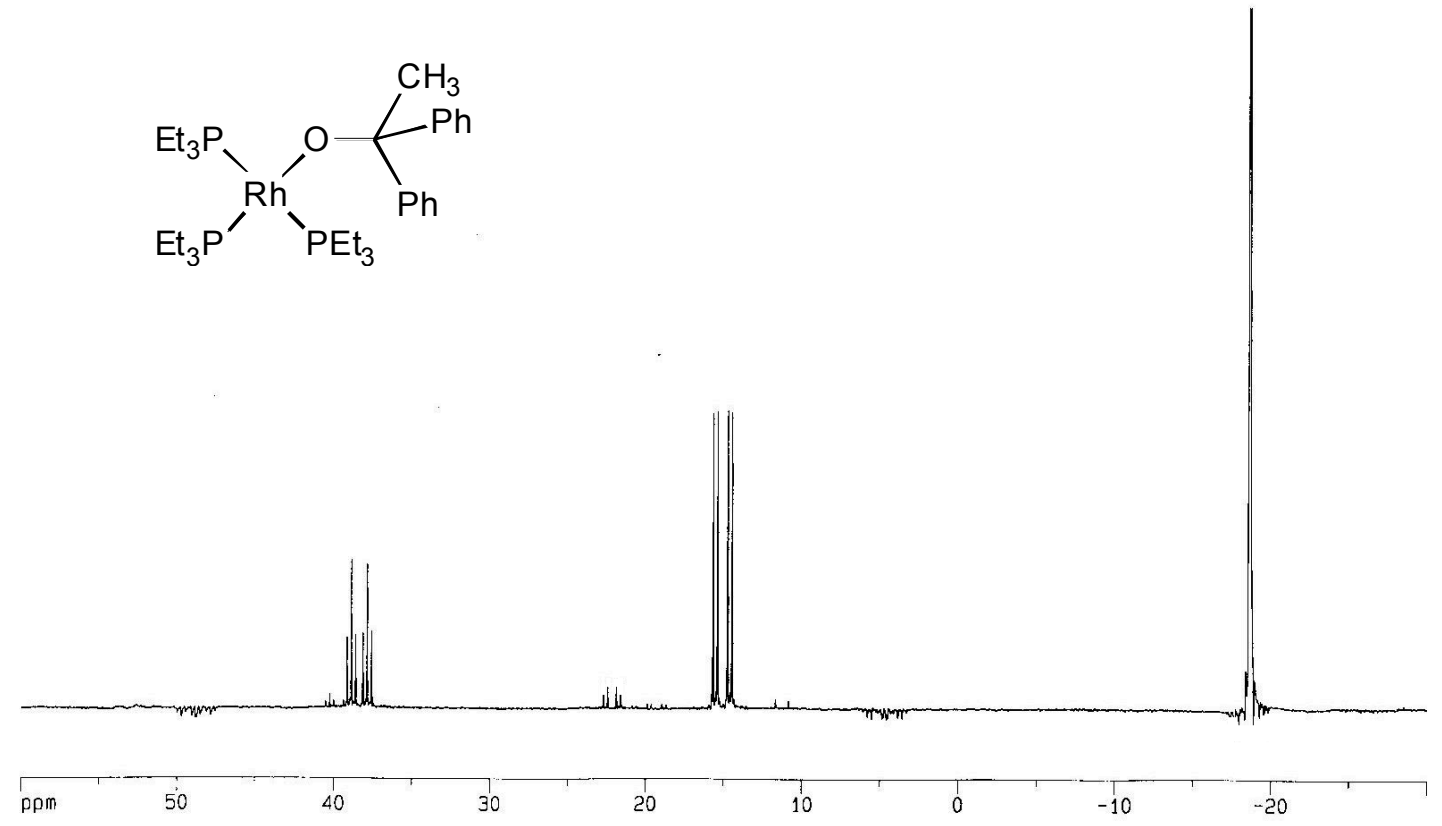

Figure S4. ${ }^{31} \mathrm{P}$ NMR spectrum $\left(161.9 \mathrm{MHz}\right.$, THF- $\left.d_{8},-20{ }^{\circ} \mathrm{C}\right)$ of $\left(\mathrm{PEt}_{3}\right)_{3} \mathrm{RhOC}(\mathrm{Me}) \mathrm{Ph}_{2}(\mathbf{3 b})$ in the presence of added $\mathrm{PEt}_{3}(\sim 5$ equiv $)$. 


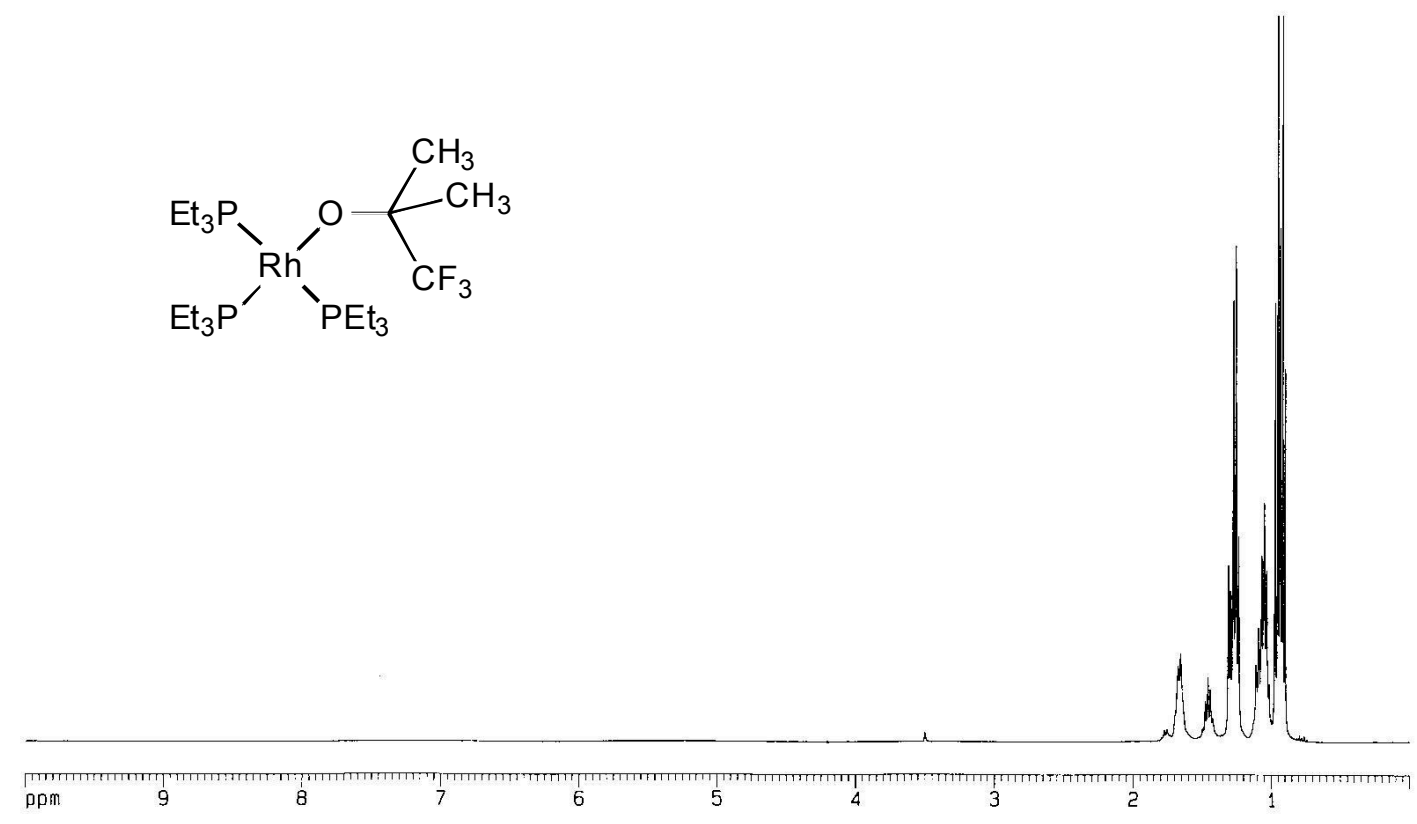

Figure S5. ${ }^{1} \mathrm{H}$ NMR spectrum $\left(400 \mathrm{MHz}, \mathrm{THF}-d_{8},-20{ }^{\circ} \mathrm{C}\right)$ of $\left(\mathrm{PEt}_{3}\right)_{3} \mathrm{RhOC}\left(\mathrm{CF}_{3}\right) \mathrm{Me}_{2}(\mathbf{3 e})$ in the presence of added $\mathrm{PEt}_{3}(\sim 5$ equiv $)$. 


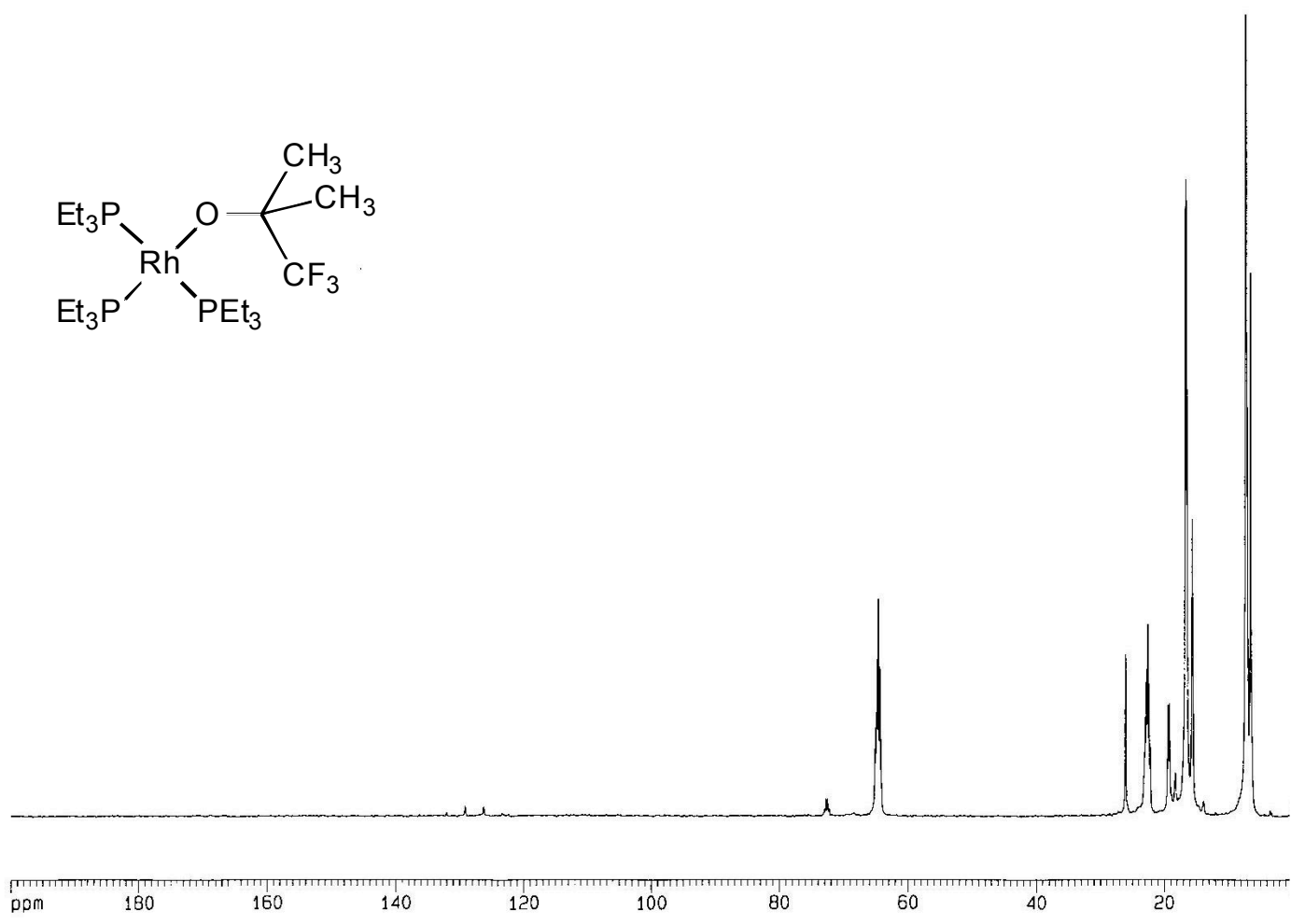

Figure S6. ${ }^{13} \mathrm{C}$ NMR spectrum $\left(100.6 \mathrm{MHz}\right.$, THF- $\left.d_{8},-20{ }^{\circ} \mathrm{C}\right)$ of $\left(\mathrm{PEt}_{3}\right)_{3} \mathrm{RhOC}\left(\mathrm{CF}_{3}\right) \mathrm{Me}_{2}(\mathbf{3 e})$ in the presence of added $\mathrm{PEt}_{3}(\sim 5$ equiv). 


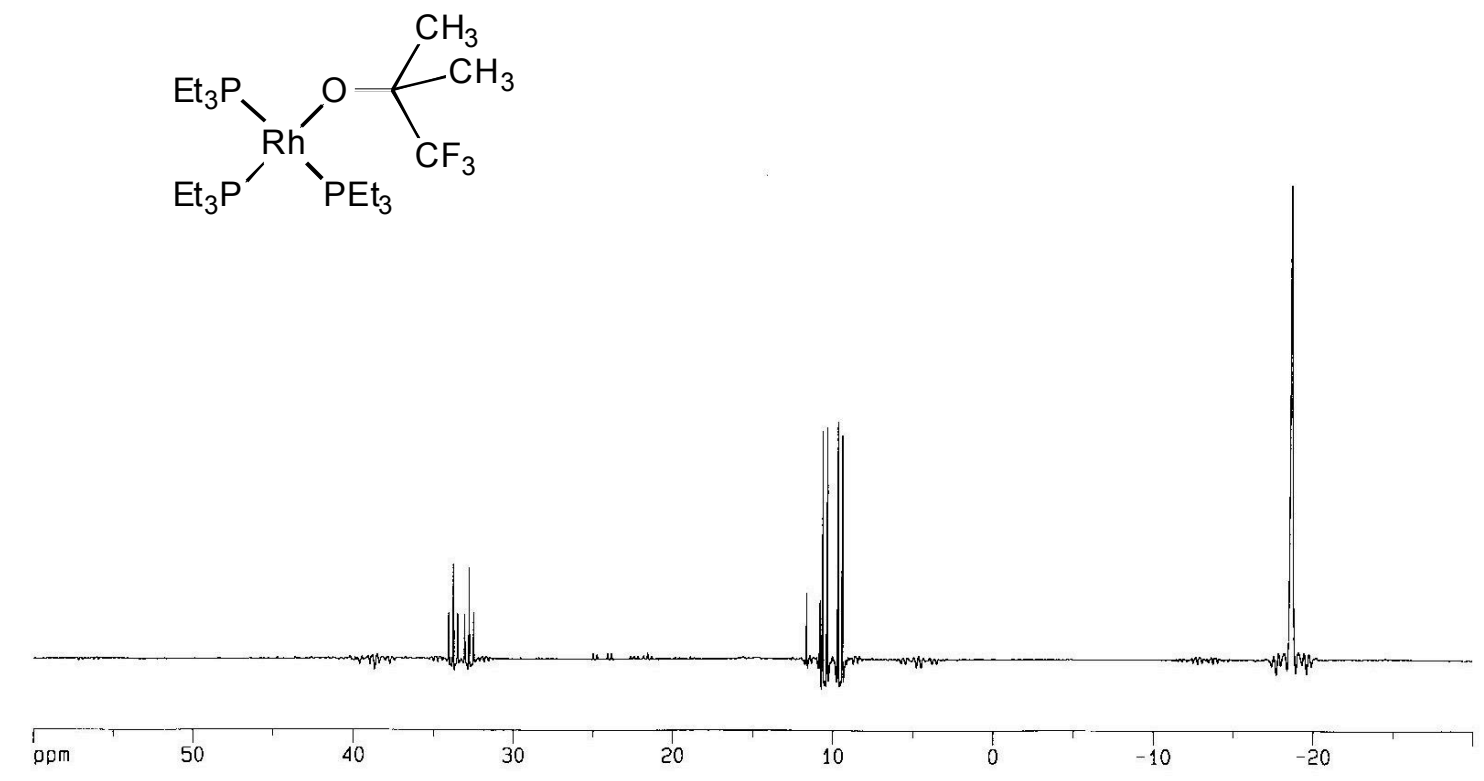

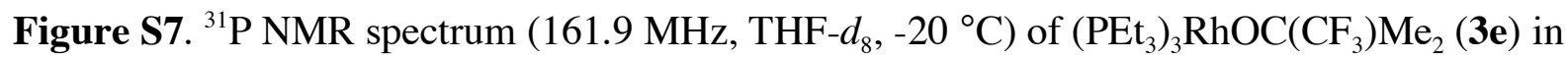
the presence of added $\mathrm{PEt}_{3}(\sim 5$ equiv). 

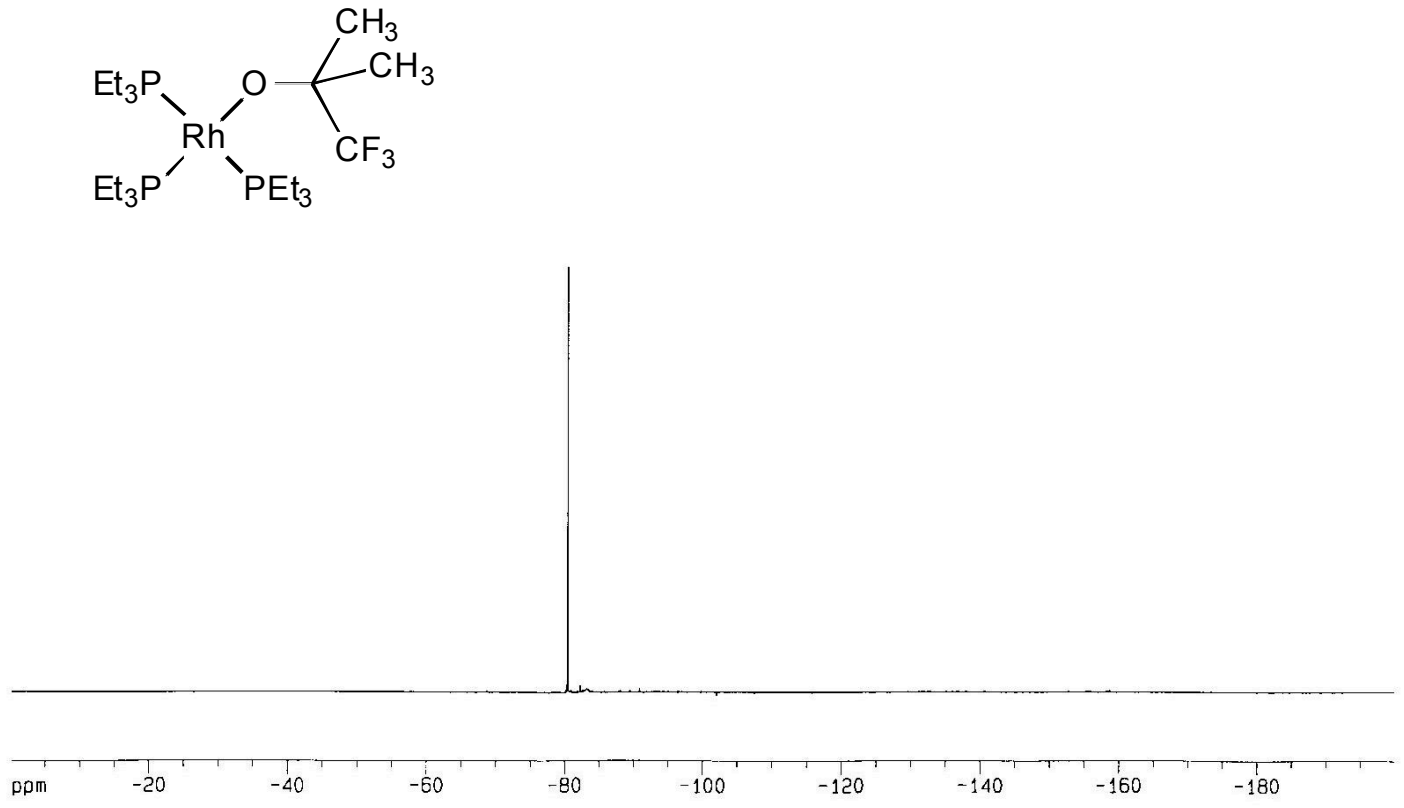

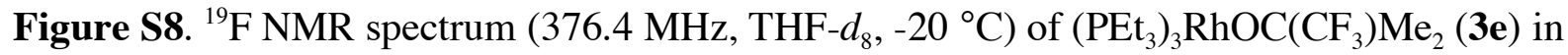
the presence of added $\mathrm{PEt}_{3}(\sim 5$ equiv). 
Experimental Procedure for the X-ray Diffraction of $\left(\mathrm{PEt}_{3}\right)_{2} \mathrm{RhOCPh}_{3}(\mathbf{2 a})$

\section{Data Collection}

A red block crystal of $\mathrm{C}_{31} \mathrm{H}_{45} \mathrm{OP}_{2} \mathrm{Rh}$ having approximate dimensions of $0.10 \times 0.10 \times 0.10$ $\mathrm{mm}^{3}$ was mounted with epoxy cement on the tip of a fine glass fiber. All measurements were made on a Nonius KappaCCD diffractometer with graphite monochromated Mo-Ka radiation.

Cell constants and an orientation matrix for data collection corresponded to a primitive monoclinic cell with dimensions:

$$
\begin{array}{ll}
\mathrm{a}=8.8744(18) \AA & \alpha=90^{\circ} \\
\mathrm{b}=19.153(4) \AA & \beta=108.67(3) \mathrm{O} \\
\mathrm{c}=9.2647(19) \AA & \gamma=90^{\circ} \\
\mathrm{V}=1491.8(5) \AA^{3} &
\end{array}
$$

For $\mathrm{Z}=2$ and F.W. $=598.52$, the calculated density is $1.332 \mathrm{~g} / \mathrm{cm}^{3}$. Based on a statistical analysis of intensity distribution, and the successful solution and refinement of the structure, the space group was determined to be $P 2_{1}$ (\#4).

The data were collected at a temperature of $173(2) \mathrm{K}$ to a maximum $2 \theta$ value of $56.72^{\circ}$. Five omega scans consisting of 69,75,59,64, and 19 data frames, respectively, were collected with a frame width of $1.0^{\circ}$ and a detector-to-crystal distance, Dx, of $35.0 \mathrm{~mm}$. Each frame was exposed twice (for the purpose of de-zingering) for a total of $40 \mathrm{~s}$. The data frames were processed and scaled using the DENZO software package. ${ }^{1}$

\section{Data Reduction}

A total of 6708 reflections were collected of which 6708 were unique and observed $\left(\mathrm{R}_{\text {int }}\right.$ $=0.00$, Friedel pairs not merged). The linear absorption coefficient, $\mu$, for Mo-K $\alpha$ radiation is $7.01 \mathrm{~cm}^{-1}$, and no absorption correction was applied. The data were corrected for Lorentz and polarization effects.

\section{$\underline{\text { Structure Solution and Refinement }}$}

The structure was solved by direct methods and expanded using Fourier techniques ${ }^{2}$. The non-hydrogen atoms were refined anisotropically and hydrogen atoms were treated as idealized contributions. The final cycle of full-matrix least-squares refinement ${ }^{3}$ on $\mathrm{F}$ was based on 6708 observed reflections (I > 2.00б(I)) and 317 variable parameters and converged with unweighted and weighted agreement factors of:

$$
\begin{gathered}
\mathrm{R}=\Sigma\|\mathrm{Fol}-|\mathrm{Fc} \| / \Sigma| \mathrm{Fo} \mid=0.0431 \\
\mathrm{R}_{\mathrm{W}}=\left\{\Sigma\left[\mathrm{w}\left(\mathrm{F}_{\mathrm{o}}^{2}-\mathrm{F}_{\mathrm{c}}^{2}\right)^{2}\right] / \Sigma\left[\mathrm{w}\left(\mathrm{F}_{\mathrm{o}}^{2}\right)^{2}\right]\right\}^{1 / 2}=0.0877
\end{gathered}
$$

The maximum and minimum peaks on the final difference Fourier map corresponded to 0.610 and $-0.988 \mathrm{e}^{-} / \AA^{3}$ respectively. 


\section{References for the X-ray diffraction study}

(1) Z. Otwinowski and W. Minor, "Processing of X-Ray Diffraction Data Collected in Oscillation Mode," Methods in Enzymology, vol. 276: Macromolecular Crystallography, part A, 307-326, 1997, C.W. Carter, Jr. \& R.M. Sweet, Eds., Academic Press.

(2) Acta Cryst. A46 (1990) 467-473

(3) Least Squares function minimized:

$$
\Sigma w\left(\mathrm{~F}_{\mathrm{o}}^{2}-\mathrm{F}_{\mathrm{c}}^{2}\right)^{2}
$$


Table S1. Crystal data and structure refinement for $\mathbf{2 a}$.

Empirical formula

Formula weight

Temperature

Wavelength

Crystal system

Space group

Unit cell dimensions

Volume

$\mathrm{Z}$

Density (calculated)

Absorption coefficient

$\mathrm{F}(000)$

Crystal size

Theta range for data collection

Index ranges

Reflections collected

Independent reflections

Completeness to theta $=28.36^{\circ}$

Absorption correction

Max. and min. transmission

Refinement method

Data / restraints / parameters

Goodness-of-fit on $\mathrm{F}^{2}$

Final $\mathrm{R}$ indices [I $>2 \operatorname{sigma}(\mathrm{I})]$

$\mathrm{R}$ indices (all data)

Absolute structure parameter

Largest diff. peak and hole
$\mathrm{C}_{31} \mathrm{H}_{45} \mathrm{O} \mathrm{P}_{2} \mathrm{Rh}$

598.52

173(2) K

$0.71073 \AA$

Monoclinic

P2(1)

$a=8.8744(18) \AA \quad \alpha=90^{\circ}$.

$\mathrm{b}=19.153(4) \AA$

$\beta=108.67(3)^{\circ}$.

$\mathrm{c}=9.2647(19) \AA$

$1491.8(5) \AA^{3}$

2

$1.332 \mathrm{~g} / \mathrm{cm}^{3}$

$7.01 \mathrm{~cm}^{-1}$

628

$0.10 \times 0.10 \times 0.10 \mathrm{~mm}^{3}$

2.55 to $28.36^{\circ}$.

$-11<=\mathrm{h}<=11,-24<=\mathrm{k}<=25,-12<=\mathrm{l}<=12$

6708

$6708[\mathrm{R}(\mathrm{int})=0.0000]$

$98.3 \%$

None

0.9332 and 0.9332

Full-matrix least-squares on $\mathrm{F}^{2}$

$6708 / 1 / 317$

1.020

$\mathrm{R} 1=0.0431, \mathrm{wR} 2=0.0877$

$\mathrm{R} 1=0.0634, \mathrm{wR} 2=0.0948$

$0.38(3)$

0.610 and -0.988 e. $\AA^{-3}$ 
Table S2. Atomic coordinates $\left(\times 10^{4}\right)$ and equivalent isotropic displacement parameters $\left(\AA^{2} \times 10^{3}\right)$ for $2 \mathbf{a}$. U(eq) is defined as one third of the trace of the orthogonalized $\mathrm{U}^{\mathrm{ij}}$ tensor.

\begin{tabular}{|c|c|c|c|c|}
\hline & $\mathrm{x}$ & $\mathrm{y}$ & $\mathrm{z}$ & $\mathrm{U}(\mathrm{eq})$ \\
\hline $\mathrm{Rh}(1)$ & $6560(1)$ & $2002(1)$ & $4513(1)$ & $22(1)$ \\
\hline $\mathrm{P}(1)$ & $5499(1)$ & $2350(1)$ & 2104(1) & $27(1)$ \\
\hline $\mathrm{P}(2)$ & $7217(1)$ & $3054(1)$ & $5535(1)$ & $29(1)$ \\
\hline $\mathrm{O}(1)$ & $7227(3)$ & $1601(2)$ & $6699(3)$ & $28(1)$ \\
\hline$C(1)$ & $6658(5)$ & $2226(3)$ & $796(5)$ & $40(1)$ \\
\hline$C(2)$ & $8262(6)$ & $2585(4)$ & $1346(6)$ & $58(2)$ \\
\hline$C(3)$ & $4775(6)$ & $3252(2)$ & $1716(5)$ & $35(1)$ \\
\hline$C(4)$ & $4095(8)$ & $3483(3)$ & $60(6)$ & $61(2)$ \\
\hline$C(5)$ & $3697(5)$ & $1866(3)$ & $1079(6)$ & $41(1)$ \\
\hline$C(6)$ & $2410(5)$ & $1879(4)$ & $1837(6)$ & $61(2)$ \\
\hline$C(7)$ & $8533(7)$ & $3608(3)$ & $4848(6)$ & $50(1)$ \\
\hline$C(8)$ & $9089(9)$ & $4295(3)$ & $5761(7)$ & $74(2)$ \\
\hline $\mathrm{C}(9)$ & $5640(7)$ & $3668(3)$ & $5587(6)$ & $50(1)$ \\
\hline$C(10)$ & $4259(7)$ & $3325(3)$ & $5916(7)$ & $55(2)$ \\
\hline$C(11)$ & $8303(6)$ & $2969(3)$ & $7550(6)$ & $48(1)$ \\
\hline$C(12)$ & $9925(6)$ & $2639(4)$ & $7856(6)$ & $59(2)$ \\
\hline$C(13)$ & $6666(5)$ & $910(2)$ & $6422(5)$ & $25(1)$ \\
\hline$C(14)$ & $6471(5)$ & $781(2)$ & $4718(5)$ & $27(1)$ \\
\hline$C(15)$ & $7793(6)$ & $919(2)$ & $4233(5)$ & $31(1)$ \\
\hline$C(16)$ & $7834(6)$ & $699(3)$ & $2815(5)$ & $37(1)$ \\
\hline$C(17)$ & $6536(7)$ & $357(3)$ & $1834(6)$ & $46(1)$ \\
\hline$C(18)$ & $5228(7)$ & $224(3)$ & $2278(6)$ & $46(1)$ \\
\hline$C(19)$ & $5166(5)$ & $437(2)$ & $3677(5)$ & $32(1)$ \\
\hline$C(20)$ & $7884(5)$ & $402(2)$ & $7421(5)$ & $29(1)$ \\
\hline$C(21)$ & $8098(5)$ & $-269(2)$ & $6933(6)$ & $35(1)$ \\
\hline$C(22)$ & $9193(6)$ & $-718(3)$ & $7917(6)$ & $44(1)$ \\
\hline$C(23)$ & $10058(6)$ & $-510(3)$ & $9353(6)$ & $50(1)$ \\
\hline$C(24)$ & $9852(6)$ & 153(3) & $9844(6)$ & $43(1)$ \\
\hline$C(25)$ & $8770(6)$ & $605(3)$ & $8887(5)$ & $36(1)$ \\
\hline$C(26)$ & $5074(6)$ & $835(2)$ & $6719(5)$ & $31(1)$ \\
\hline$C(27)$ & $4685(5)$ & $268(3)$ & $7467(5)$ & $35(1)$ \\
\hline
\end{tabular}




\begin{tabular}{lrrrr}
$\mathrm{C}(28)$ & $3233(6)$ & $239(3)$ & $7735(5)$ & $42(1)$ \\
$\mathrm{C}(29)$ & $2153(6)$ & $773(3)$ & $7255(6)$ & $52(2)$ \\
$\mathrm{C}(30)$ & $2498(6)$ & $1324(3)$ & $6496(7)$ & $54(2)$ \\
$\mathrm{C}(31)$ & $3948(5)$ & $1360(3)$ & $6237(6)$ & $44(1)$ \\
\hline
\end{tabular}


Table S3. Bond lengths $[\AA]$ and angles $\left[{ }^{\circ}\right]$ for $\mathbf{2 a}$.

\begin{tabular}{|c|c|c|c|}
\hline $\mathrm{Rh}(1)-\mathrm{O}(1)$ & $2.069(3)$ & $C(26)-C(27)$ & $1.390(6)$ \\
\hline $\mathrm{Rh}(1)-\mathrm{P}(2)$ & $2.2220(12)$ & $\mathrm{C}(27)-\mathrm{C}(28)$ & $1.389(6)$ \\
\hline $\mathrm{Rh}(1)-\mathrm{P}(1)$ & $2.2282(13)$ & $\mathrm{C}(28)-\mathrm{C}(29)$ & $1.374(8)$ \\
\hline $\mathrm{Rh}(1)-\mathrm{C}(14)$ & $2.350(4)$ & $\mathrm{C}(29)-\mathrm{C}(30)$ & $1.357(8)$ \\
\hline $\operatorname{Rh}(1)-C(15)$ & $2.398(4)$ & $C(30)-C(31)$ & $1.384(6)$ \\
\hline$P(1)-C(5)$ & $1.829(5)$ & $\mathrm{O}(1)-\mathrm{Rh}(1)-\mathrm{P}(2)$ & $88.05(9)$ \\
\hline $\mathrm{P}(1)-\mathrm{C}(1)$ & $1.839(4)$ & $\mathrm{O}(1)-\mathrm{Rh}(1)-\mathrm{P}(1)$ & $171.38(8)$ \\
\hline $\mathrm{P}(1)-\mathrm{C}(3)$ & $1.839(5)$ & $\mathrm{P}(2)-\mathrm{Rh}(1)-\mathrm{P}(1)$ & $97.21(5)$ \\
\hline $\mathrm{P}(2)-\mathrm{C}(11)$ & $1.813(5)$ & $\mathrm{O}(1)-\mathrm{Rh}(1)-\mathrm{C}(14)$ & $63.70(14)$ \\
\hline$P(2)-C(7)$ & $1.837(5)$ & $\mathrm{P}(2)-\mathrm{Rh}(1)-\mathrm{C}(14)$ & $151.45(12)$ \\
\hline $\mathrm{P}(2)-\mathrm{C}(9)$ & $1.841(5)$ & $\mathrm{P}(1)-\mathrm{Rh}(1)-\mathrm{C}(14)$ & $111.34(11)$ \\
\hline $\mathrm{O}(1)-\mathrm{C}(13)$ & $1.407(5)$ & $\mathrm{O}(1)-\mathrm{Rh}(1)-\mathrm{C}(15)$ & $77.68(13)$ \\
\hline $\mathrm{C}(1)-\mathrm{C}(2)$ & $1.515(7)$ & $\mathrm{P}(2)-\mathrm{Rh}(1)-\mathrm{C}(15)$ & $139.77(12)$ \\
\hline$C(3)-C(4)$ & $1.523(7)$ & $\mathrm{P}(1)-\mathrm{Rh}(1)-\mathrm{C}(15)$ & $102.19(11)$ \\
\hline$C(5)-C(6)$ & $1.521(6)$ & $\mathrm{C}(14)-\mathrm{Rh}(1)-\mathrm{C}(15)$ & $34.51(14)$ \\
\hline$C(7)-C(8)$ & $1.557(8)$ & $\mathrm{C}(5)-\mathrm{P}(1)-\mathrm{C}(1)$ & $100.0(2)$ \\
\hline $\mathrm{C}(9)-\mathrm{C}(10)$ & $1.505(8)$ & $\mathrm{C}(5)-\mathrm{P}(1)-\mathrm{C}(3)$ & $100.5(2)$ \\
\hline $\mathrm{C}(11)-\mathrm{C}(12)$ & $1.513(8)$ & $\mathrm{C}(1)-\mathrm{P}(1)-\mathrm{C}(3)$ & $103.1(2)$ \\
\hline$C(13)-C(20)$ & $1.528(6)$ & $\mathrm{C}(5)-\mathrm{P}(1)-\mathrm{Rh}(1)$ & $112.81(16)$ \\
\hline$C(13)-C(26)$ & $1.530(6)$ & $\mathrm{C}(1)-\mathrm{P}(1)-\mathrm{Rh}(1)$ & $118.40(16)$ \\
\hline$C(13)-C(14)$ & $1.552(6)$ & $\mathrm{C}(3)-\mathrm{P}(1)-\mathrm{Rh}(1)$ & $119.04(16)$ \\
\hline$C(14)-C(15)$ & $1.409(6)$ & $\mathrm{C}(11)-\mathrm{P}(2)-\mathrm{C}(7)$ & $102.8(3)$ \\
\hline$C(14)-C(19)$ & $1.411(6)$ & $\mathrm{C}(11)-\mathrm{P}(2)-\mathrm{C}(9)$ & $100.9(3)$ \\
\hline$C(15)-C(16)$ & $1.391(6)$ & $\mathrm{C}(7)-\mathrm{P}(2)-\mathrm{C}(9)$ & $102.3(3)$ \\
\hline$C(16)-C(17)$ & $1.382(7)$ & $\mathrm{C}(11)-\mathrm{P}(2)-\mathrm{Rh}(1)$ & $109.75(19)$ \\
\hline $\mathrm{C}(17)-\mathrm{C}(18)$ & $1.374(7)$ & $\mathrm{C}(7)-\mathrm{P}(2)-\mathrm{Rh}(1)$ & $119.04(19)$ \\
\hline$C(18)-C(19)$ & $1.376(7)$ & $\mathrm{C}(9)-\mathrm{P}(2)-\mathrm{Rh}(1)$ & $119.51(19)$ \\
\hline$C(20)-C(25)$ & $1.389(7)$ & $\mathrm{C}(13)-\mathrm{O}(1)-\mathrm{Rh}(1)$ & $101.4(2)$ \\
\hline$C(20)-C(21)$ & $1.395(6)$ & $\mathrm{C}(2)-\mathrm{C}(1)-\mathrm{P}(1)$ & $112.6(3)$ \\
\hline$C(21)-C(22)$ & $1.396(7)$ & $\mathrm{C}(4)-\mathrm{C}(3)-\mathrm{P}(1)$ & $118.0(4)$ \\
\hline$C(22)-C(23)$ & $1.365(8)$ & $\mathrm{C}(6)-\mathrm{C}(5)-\mathrm{P}(1)$ & $114.3(4)$ \\
\hline$C(23)-C(24)$ & $1.380(8)$ & $C(8)-C(7)-P(2)$ & $115.2(4)$ \\
\hline$C(24)-C(25)$ & $1.383(7)$ & $\mathrm{C}(10)-\mathrm{C}(9)-\mathrm{P}(2)$ & $113.6(4)$ \\
\hline$C(26)-C(31)$ & $1.387(7)$ & $\mathrm{C}(12)-\mathrm{C}(11)-\mathrm{P}(2)$ & $113.0(4)$ \\
\hline
\end{tabular}




$\begin{array}{lr}\mathrm{O}(1)-\mathrm{C}(13)-\mathrm{C}(20) & 110.3(3) \\ \mathrm{O}(1)-\mathrm{C}(13)-\mathrm{C}(26) & 110.4(3) \\ \mathrm{C}(20)-\mathrm{C}(13)-\mathrm{C}(26) & 110.2(3) \\ \mathrm{O}(1)-\mathrm{C}(13)-\mathrm{C}(14) & 104.7(3) \\ \mathrm{C}(20)-\mathrm{C}(13)-\mathrm{C}(14) & 110.0(3) \\ \mathrm{C}(26)-\mathrm{C}(13)-\mathrm{C}(14) & 111.1(3) \\ \mathrm{C}(15)-\mathrm{C}(14)-\mathrm{C}(19) & 117.0(4) \\ \mathrm{C}(15)-\mathrm{C}(14)-\mathrm{C}(13) & 117.5(4) \\ \mathrm{C}(19)-\mathrm{C}(14)-\mathrm{C}(13) & 124.7(4) \\ \mathrm{C}(15)-\mathrm{C}(14)-\mathrm{Rh}(1) & 74.6(2) \\ \mathrm{C}(19)-\mathrm{C}(14)-\mathrm{Rh}(1) & 116.9(3) \\ \mathrm{C}(13)-\mathrm{C}(14)-\mathrm{Rh}(1) & 85.9(2) \\ \mathrm{C}(16)-\mathrm{C}(15)-\mathrm{C}(14) & 121.4(4) \\ \mathrm{C}(16)-\mathrm{C}(15)-\mathrm{Rh}(1) & 121.0(3) \\ \mathrm{C}(14)-\mathrm{C}(15)-\mathrm{Rh}(1) & 70.9(2) \\ \mathrm{C}(17)-\mathrm{C}(16)-\mathrm{C}(15) & 119.7(4) \\ \mathrm{C}(18)-\mathrm{C}(17)-\mathrm{C}(16) & 119.9(5) \\ \mathrm{C}(19)-\mathrm{C}(18)-\mathrm{C}(17) & 121.3(5) \\ \mathrm{C}(18)-\mathrm{C}(19)-\mathrm{C}(14) & 120.7(4) \\ \mathrm{C}(25)-\mathrm{C}(20)-\mathrm{C}(21) & 118.8(4) \\ \mathrm{C}(25)-\mathrm{C}(20)-\mathrm{C}(13) & 118.9(4) \\ \mathrm{C}(21)-\mathrm{C}(20)-\mathrm{C}(13) & 122.3(4) \\ \mathrm{C}(20)-\mathrm{C}(21)-\mathrm{C}(22) & 119.6(5) \\ \mathrm{C}(23)-\mathrm{C}(22)-\mathrm{C}(21) & 120.9(5) \\ \mathrm{C}(22)-\mathrm{C}(23)-\mathrm{C}(24) & 119.8(5) \\ \mathrm{C}(23)-\mathrm{C}(24)-\mathrm{C}(25) & 120.2(5) \\ \mathrm{C}(24)-\mathrm{C}(25)-\mathrm{C}(20) & 120.7(5) \\ \mathrm{C}(31)-\mathrm{C}(26)-\mathrm{C}(27) & 117.3(4) \\ \mathrm{C}(31)-\mathrm{C}(26)-\mathrm{C}(13) & 119.0(4) \\ \mathrm{C}(27)-\mathrm{C}(26)-\mathrm{C}(13) & 123.7(4) \\ \mathrm{C}(26)-\mathrm{C}(27)-\mathrm{C}(28) & 120.8(5) \\ \mathrm{C}(29)-\mathrm{C}(28)-\mathrm{C}(27) & 120.3(5) \\ \mathrm{C}(30)-\mathrm{C}(29)-\mathrm{C}(28) & 119.8(5) \\ \mathrm{C}(29)-\mathrm{C}(30)-\mathrm{C}(31) & 120.3(5) \\ \mathrm{C}(30)-\mathrm{C}(31)-\mathrm{C}(26) & 121.5(5)\end{array}$


Table S4. Anisotropic displacement parameters $\left(\AA^{2} \times 10^{3}\right)$ for 2a. The anisotropic displacement factor exponent takes the form: $-2 \pi^{2}\left[h^{2} a^{*} 2 U^{11}+\ldots+2 h k a^{*} b^{*} U^{12}\right]$

$$
\begin{array}{llllll}
\mathrm{U}^{11} & \mathrm{U}^{22} & \mathrm{U}^{33} & \mathrm{U}^{23} & \mathrm{U}^{13} & \mathrm{U}^{12}
\end{array}
$$

\begin{tabular}{|c|c|c|c|c|c|c|}
\hline $\mathrm{Rh}(1)$ & $25(1)$ & $22(1)$ & $20(1)$ & 1(1) & $7(1)$ & 1(1) \\
\hline $\mathrm{P}(1)$ & $30(1)$ & $28(1)$ & 21(1) & 2(1) & $5(1)$ & 1(1) \\
\hline $\mathrm{P}(2)$ & $35(1)$ & $23(1)$ & $27(1)$ & $-2(1)$ & $9(1)$ & $-2(1)$ \\
\hline $\mathrm{O}(1)$ & $36(2)$ & $25(2)$ & $22(2)$ & $4(1)$ & $7(1)$ & $-2(1)$ \\
\hline $\mathrm{C}(1)$ & $46(3)$ & $48(3)$ & $26(2)$ & $4(2)$ & $12(2)$ & $3(2)$ \\
\hline $\mathrm{C}(2)$ & $45(3)$ & $93(5)$ & $42(3)$ & $10(3)$ & 21(3) & $-5(3)$ \\
\hline$C(3)$ & $39(3)$ & $25(3)$ & $34(3)$ & $7(2)$ & 1(2) & $1(2)$ \\
\hline $\mathrm{C}(4)$ & $82(4)$ & $43(4)$ & $37(3)$ & $8(3)$ & $-8(3)$ & $0(3)$ \\
\hline$C(5)$ & $43(3)$ & $34(4)$ & $40(2)$ & $1(2)$ & $3(2)$ & $-4(2)$ \\
\hline$C(6)$ & $33(3)$ & $76(6)$ & $62(3)$ & $8(3)$ & $1(2)$ & $-14(3)$ \\
\hline$C(7)$ & $64(4)$ & $43(3)$ & $37(3)$ & $-2(3)$ & $6(3)$ & $-23(3)$ \\
\hline $\mathrm{C}(8)$ & $100(5)$ & $57(4)$ & $52(4)$ & $5(3)$ & $6(3)$ & $-43(4)$ \\
\hline C(9) & $67(4)$ & $35(3)$ & $46(3)$ & $-2(3)$ & $17(3)$ & $5(3)$ \\
\hline$C(10)$ & $62(4)$ & $52(4)$ & $62(4)$ & $17(3)$ & $35(3)$ & $26(3)$ \\
\hline$C(11)$ & $62(4)$ & $43(3)$ & $31(3)$ & $-1(2)$ & $5(2)$ & $-10(3)$ \\
\hline$C(12)$ & $40(3)$ & $80(5)$ & $51(4)$ & $2(3)$ & $5(3)$ & $-15(3)$ \\
\hline$C(13)$ & $30(2)$ & $21(2)$ & $23(2)$ & 2(2) & $6(2)$ & $4(2)$ \\
\hline$C(14)$ & $35(3)$ & $16(2)$ & $30(3)$ & $6(2)$ & $11(2)$ & $5(2)$ \\
\hline$C(15)$ & $41(3)$ & $22(2)$ & $33(3)$ & $2(2)$ & $15(2)$ & $4(2)$ \\
\hline$C(16)$ & $49(3)$ & $32(3)$ & $37(3)$ & $4(2)$ & $23(2)$ & $7(2)$ \\
\hline$C(17)$ & $78(4)$ & $29(3)$ & $39(3)$ & $-1(2)$ & $28(3)$ & 11(3) \\
\hline$C(18)$ & $63(4)$ & $32(3)$ & $34(3)$ & $2(2)$ & $3(2)$ & $-9(2)$ \\
\hline$C(19)$ & $37(3)$ & $29(3)$ & $29(3)$ & $0(2)$ & $8(2)$ & $-3(2)$ \\
\hline$C(20)$ & $31(2)$ & $29(2)$ & $32(3)$ & $8(2)$ & $16(2)$ & $3(2)$ \\
\hline$C(21)$ & $36(3)$ & $29(3)$ & $43(3)$ & $5(2)$ & $14(2)$ & $3(2)$ \\
\hline$C(22)$ & $50(3)$ & $34(3)$ & $53(4)$ & $15(3)$ & $23(3)$ & $15(2)$ \\
\hline$C(23)$ & $44(3)$ & 61(4) & $45(3)$ & $26(3)$ & $16(3)$ & 19(3) \\
\hline$C(24)$ & $41(3)$ & $59(4)$ & $27(3)$ & 11(3) & $7(2)$ & 11(3) \\
\hline$C(25)$ & 41(3) & $43(3)$ & $28(3)$ & $7(2)$ & $17(2)$ & $10(2)$ \\
\hline$C(26)$ & $37(3)$ & $33(3)$ & $24(2)$ & $-1(2)$ & $13(2)$ & $-1(2)$ \\
\hline$C(27)$ & $35(3)$ & $38(3)$ & $34(3)$ & $4(2)$ & $14(2)$ & $-3(2)$ \\
\hline$C(28)$ & $38(3)$ & $55(3)$ & $36(3)$ & $8(3)$ & $16(2)$ & $-10(2)$ \\
\hline
\end{tabular}




$\begin{array}{lllllll}\mathrm{C}(29) & 35(3) & 78(4) & 49(3) & -7(3) & 23(3) & -7(3) \\ \mathrm{C}(30) & 33(3) & 64(4) & 71(4) & 6(3) & 24(3) & 16(3) \\ \mathrm{C}(31) & 38(3) & 45(3) & 53(3) & 11(3) & 20(2) & 8(2)\end{array}$


Table S5. Hydrogen coordinates ( $\left.x 10^{4}\right)$ and isotropic displacement parameters $\left(\AA^{2} \times 10^{3}\right)$ for $\mathbf{2 a}$.

\begin{tabular}{|c|c|c|c|c|}
\hline & $\mathrm{x}$ & $\mathrm{y}$ & $\mathrm{z}$ & $\mathrm{U}(\mathrm{eq})$ \\
\hline $\mathrm{H}(1 \mathrm{~A})$ & 6820 & 1721 & 682 & 48 \\
\hline $\mathrm{H}(1 \mathrm{~B})$ & 6045 & 2413 & -220 & 48 \\
\hline $\mathrm{H}(2 \mathrm{~A})$ & 8832 & 2505 & 613 & 88 \\
\hline $\mathrm{H}(2 \mathrm{~B})$ & 8883 & 2396 & 2341 & 88 \\
\hline $\mathrm{H}(2 \mathrm{C})$ & 8109 & 3088 & 1439 & 88 \\
\hline $\mathrm{H}(3 \mathrm{~A})$ & 3942 & 3324 & 2202 & 42 \\
\hline $\mathrm{H}(3 \mathrm{~B})$ & 5667 & 3569 & 2231 & 42 \\
\hline $\mathrm{H}(4 \mathrm{~A})$ & 3769 & 3973 & 20 & 91 \\
\hline $\mathrm{H}(4 \mathrm{~B})$ & 3172 & 3193 & -464 & 91 \\
\hline $\mathrm{H}(4 \mathrm{C})$ & 4909 & 3431 & -441 & 91 \\
\hline $\mathrm{H}(5 \mathrm{~A})$ & 3255 & 2062 & 40 & 50 \\
\hline $\mathrm{H}(5 \mathrm{~B})$ & 3990 & 1374 & 975 & 50 \\
\hline $\mathrm{H}(6 \mathrm{~A})$ & 1489 & 1609 & 1224 & 91 \\
\hline $\mathrm{H}(6 \mathrm{~B})$ & 2087 & 2363 & 1919 & 91 \\
\hline $\mathrm{H}(6 \mathrm{C})$ & 2824 & 1674 & 2858 & 91 \\
\hline $\mathrm{H}(7 \mathrm{~A})$ & 9486 & 3333 & 4874 & 60 \\
\hline $\mathrm{H}(7 \mathrm{~B})$ & 7973 & 3731 & 3771 & 60 \\
\hline $\mathrm{H}(8 \mathrm{~A})$ & 9786 & 4554 & 5318 & 111 \\
\hline $\mathrm{H}(8 \mathrm{~B})$ & 9671 & 4182 & 6826 & 111 \\
\hline $\mathrm{H}(8 \mathrm{C})$ & 8159 & 4582 & 5714 & 111 \\
\hline $\mathrm{H}(9 \mathrm{~A})$ & 6102 & 4025 & 6378 & 59 \\
\hline $\mathrm{H}(9 \mathrm{~B})$ & 5242 & 3911 & 4593 & 59 \\
\hline $\mathrm{H}(10 \mathrm{~A})$ & 3470 & 3680 & 5935 & 82 \\
\hline $\mathrm{H}(10 \mathrm{~B})$ & 4637 & 3091 & 6908 & 82 \\
\hline $\mathrm{H}(10 \mathrm{C})$ & 3772 & 2981 & 5121 & 82 \\
\hline $\mathrm{H}(11 \mathrm{~A})$ & 8434 & 3437 & 8026 & 57 \\
\hline $\mathrm{H}(11 \mathrm{~B})$ & 7672 & 2681 & 8034 & 57 \\
\hline $\mathrm{H}(12 \mathrm{~A})$ & 10458 & 2608 & 8958 & 89 \\
\hline $\mathrm{H}(12 \mathrm{~B})$ & 10565 & 2926 & 7397 & 89 \\
\hline $\mathrm{H}(12 \mathrm{C})$ & 9803 & 2170 & 7410 & 89 \\
\hline
\end{tabular}




\begin{tabular}{lrrrr}
$\mathrm{H}(15 \mathrm{~A})$ & 8675 & 1167 & 4888 & 38 \\
$\mathrm{H}(16 \mathrm{~A})$ & 8750 & 783 & 2522 & 45 \\
$\mathrm{H}(17 \mathrm{~A})$ & 6548 & 215 & 856 & 56 \\
$\mathrm{H}(18 \mathrm{~A})$ & 4349 & -20 & 1606 & 55 \\
$\mathrm{H}(19 \mathrm{~A})$ & 4235 & 350 & 3945 & 39 \\
$\mathrm{H}(21 \mathrm{~A})$ & 7502 & -419 & 5936 & 42 \\
$\mathrm{H}(22 \mathrm{~A})$ & 9339 & -1174 & 7583 & 53 \\
$\mathrm{H}(23 \mathrm{~A})$ & 10798 & -821 & 10013 & 59 \\
$\mathrm{H}(24 \mathrm{~A})$ & 10456 & 299 & 10841 & 52 \\
$\mathrm{H}(25 \mathrm{~A})$ & 8631 & 1060 & 9236 & 43 \\
$\mathrm{H}(27 \mathrm{~A})$ & 5421 & -105 & 7799 & 42 \\
$\mathrm{H}(28 \mathrm{~A})$ & 2985 & -151 & 8252 & 51 \\
$\mathrm{H}(29 \mathrm{~A})$ & 1168 & 756 & 7454 & 62 \\
$\mathrm{H}(30 \mathrm{~A})$ & 1740 & 1687 & 6140 & 65 \\
$\mathrm{H}(31 \mathrm{~A})$ & 4177 & 1753 & 5717 & 53 \\
& & & & \\
\hline
\end{tabular}




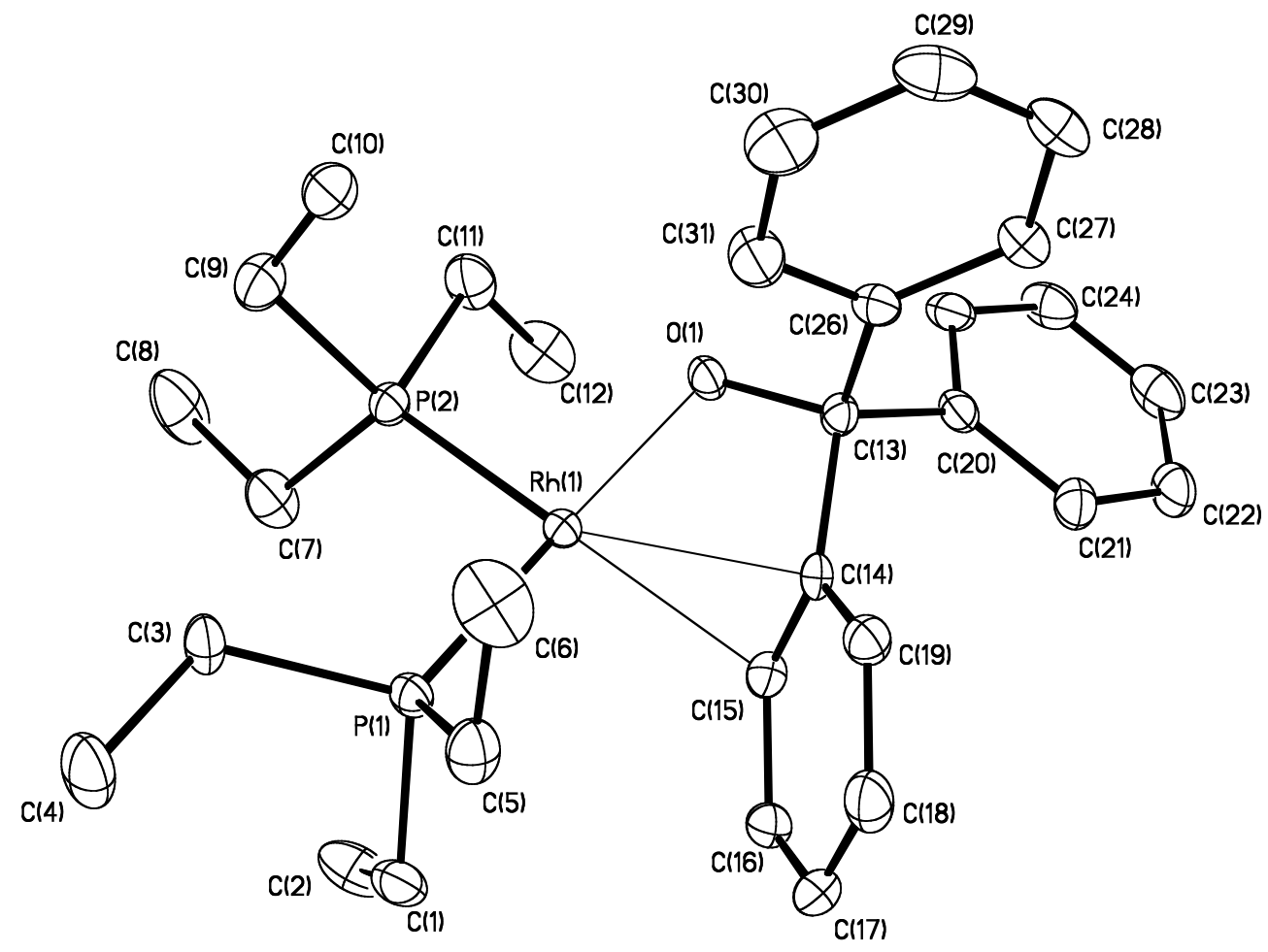

Figure S9. ORTEP diagram of $\left(\mathrm{PEt}_{3}\right)_{2} \mathrm{RhOCPh}_{3}(\mathbf{2 a})$. 